Case Study

\title{
Simulation of an isolated system behavior at high RES penetration coupled with storage
}

\author{
Athanasios Katsanevakis ${ }^{1}$ - Dimitris Konstantinidis ${ }^{1}$. Georgios Karagiannis ${ }^{1}$. Athanasios Ganias ${ }^{1}$. \\ George Karagiorgis $^{2,3} \cdot$ George Partasides $^{4} \cdot$ Demetris Petrides $^{4} \cdot$ Maria loannidou $^{4} \cdot$ Maria-Eleni Delenta $^{5}$
}

Received: 24 November 2021 / Accepted: 17 January 2022

Published online: 18 February 2022

(c) The Author(s) 2022 OPEN

\begin{abstract}
The aim of the present work is to assess the overall benefits of applying electrical energy storage, especially to isolated grids, to harvest the underlying Renewable Energy Sources potential sustainably. One such case is Cyprus, where due to various technical constraints related to the isolated nature of the island's electricity system, RES in the electricity sector can reach a maximum level assuming limited curtailments, as early as 2023-2024. To this end, simulations have been set up and run using the DISPA-SET tool to investigate the potential of new electricity storage facilities at effective accommodation of high Renewable Energy Technologies (RET) penetration, especially photovoltaics in the coming years. Results show that particularly in isolated grids, RET penetration has to be coupled with storage to avoid power curtailment and provide security to the whole system, reduce the energy not served and provide a long-term perspective for the decarbonaization in the electricity sector towards 2050 zero-emission targets.
\end{abstract}

Keywords Renewable energy · Energy storage $\cdot$ Modelling tools · Isolated electricity grid

$\begin{array}{ll}\text { Abbreviations } \\ \text { boe } & \text { Barrel of oil equivalent } \\ \text { EAC } & \text { Electricity Authority of Cyprus } \\ \text { GW } & \text { Giga Watt } \\ \text { HFO } & \text { Heavy fuel oil } \\ \text { IRENA } & \text { International Renewable Energy Agency } \\ \text { JRC } & \text { Joint Research Centre } \\ \text { LCOE } & \text { Levelized cost of energy } \\ \text { MW } & \text { Mega watt } \\ \text { MILP } & \text { Mixed Integer Linear Programming } \\ \text { NECP } & \text { National Energy and Climate Plans } \\ \text { O\&M } & \text { Operation and maintenance } \\ \text { PPM } & \text { Planned Policies and Measures } \\ \text { PV } & \text { Photovoltaic } \\ \text { RED } & \text { Renewable Energy Directive }\end{array}$

George Partasides, gpartasides@meci.gov.cy | ${ }^{1}$ KALERO Limited, Agias Aikaterinis 15, 3100 Limassol, Cyprus. ${ }^{2}$ Mechanical Engineering Department, Frederick University, 7 Y. Frederickou Street, 1036 Pallouriotissa, Nicosia, Cyprus. ${ }^{3}$ Senior Researcher, Hystore Tech Ltd, Spyrou Kyprianou 30, Ergates Industrial Area, 2643 Nicosia, Cyprus. ${ }^{4}$ Ministry of Energy, Commerce and Industry, Andrea Araouzou 13-15, 1421 Nicosia, Cyprus. ${ }^{5}$ Cyprus Energy Regulatory Authority, Agias Paraslevis 20, 2002 Strovolos, Nicosia, Cyprus.

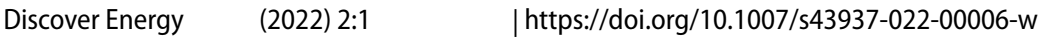




\section{RES Renewable Energy Sources}

RET Renewable Energy Technologies

SREC Storage and Renewables Electrifying Cyprus

TSO Transmission System Operator

\section{Introduction}

As the efforts for achieving energy neutrality within the EU by 2050 are increased, member states are facing multiple challenges. While the targets for 2020 have been met at a European level, there is still a long way ahead for the 2030

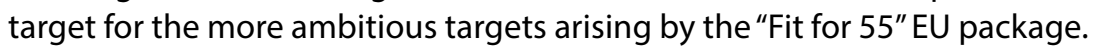

Following the publication of the Renewable Energy Directive (RED) [1] in 2008, where member states agreed upon specific targets at both national and European level, the revision of RED (2018) [2] came to propose new, more ambitious targets. Specifically, a share of at least $32 \%$ of renewable energy by 2030 at a European level has been agreed. This came as a result of cumulative efforts made by member states during the past decade that led to encouraging results regarding renewable targets. According to Eurostat [3], the share of renewables in gross final energy consumption stood at $19.7 \%$ in the EU-27 in 2019, compared with 9.6\% in 2004. The revision of the Renewable Energy Directive (2018) introduces new targets in the electricity sector to be met, with a strong emphasis on new investments in the electricity sector that also include a significant amount of capital investments in the energy infrastructure components.

Following the above, member states align their policy towards sustainability to meet the agreed targets. As such, Cyprus has published the targets and actions for the decade to come in the National Energy and Climate Plan. The target of $13 \%$ in RES for 2020 has been achieved, while the target of $23 \%$ in RES for 2030 is achievable or exceeded under certain conditions. However, to achieve this target, multiple studies [4-7] prepared by the Cyprus Government suggest that actions are required in both policy formulation, support schemes improvement, and regulated efforts to overcome the lack of non-operational electricity market in Cyprus.

The Cyprus energy system presents several unique challenges since it's still isolated from the rest of the European Union grid. At the same time, the economies of scale that can be applied in the other EU Member States cannot be used at the same level in Cyprus.

In Ref. [8] the authors presented a classification of the so-called "off-grid" systems and their challenges, including a limited amount of energy available for a restricted period reduces the acceptability of the solution and sufficient power reserve to face unexpected generation failures or load demand change. In addition, Ref. [9] are raising the fact that the reliance of RES in weather conditions (RES intermittency) is an important issue, especially in cases where the portion of Renewable power injected into the grid is relatively high, leading to a significant percentage of curtailments. The challenges of isolated systems are also presented in Ref. [10], where the authors discussed the challenges and presented a hybrid Renewable energy system paradigm.

Energy storage systems are classified into two categories. Those that are behind the meter and those that are located after the meter. Both Energy Storage systems come to address various challenges, enabling multiple services and components of the market such as Bulk Energy Services, Ancillary Services, Transmission and Distribution Infrastructure services (i.e. Voltage support, congestion etc.), and customer energy management services.

Such solutions have been studied from researchers to identify feasible solutions in both economic and practical terms in different conditions.

In Ref. [11], the authors performed a thorough review of the, at the time, available storage solutions. More specifically, they identified technologies such as flywheel, battery, supercapacitor, hydrogen pneumatic and pumped storage solutions (or new techniques that are taking advantage of gravitational energy). They classified them in terms of their specific energy and specific power. An important conclusion was that batteries are the most suitable solution for continuous energy supply.

Similarly, in Ref. [12], the authors presented an analysis of the role of storage systems in the development of smart grids. Various technologies were examined, and the importance of energy storage was outlined through two case studies. Electrical and electrochemical energy storage technologies are the first choices when considering smart grids.

An attempt to identify suitable energy storage technologies in small isolated systems has been performed in Ref. [9], with the results suggesting that BESS technology may be financially feasible while considerably decreasing the levels of RES curtailment. In other works, Ref. $[10,13,14]$ energy storage technologies are investigating their applicability in different scenarios. However, it is acceptable that no study was identified to explore all the available 
commercial storage technologies for Cyprus. Thus, the purpose of this work is to compare previous results and provide recommendations using the deliverables of this study.

Another example of assessing the RES penetration in isolated islands is presented in Ref. [15]. The authors propose the interconnection of two isolated islands in an attempt to achieve $100 \%$ renewables. Moreover, they propose a smart energy system approach, linking all fossil fuel consuming sectors, shifting demand and supply according to requirements. In Ref. [16] the authors present a comparative evaluation of central and self-dispatch management concepts for battery energy storage (BES) facilities in island power systems with a high RES penetration.

The understanding of energy systems challenges and the prediction of their behavior was enhanced through simulation and analysis tools. In Ref. [17], the authors developed a global electricity system model and evaluated the operation of power plants under various scenarios. In Ref. [18], the authors performed a link between different models to investigate the contributions to the system flexibility for cross-sectoral interactions on the future European system. The energy production of a hybrid photovoltaic system associated with a storage system in an isolated site has been modeled in Ref. [19].

As stated in Ref. [20], isolated grids face the challenge of developing reliable and self-sufficient renewable energy systems is amplified due to the lack of grid flexibility options. The authors propose a novel optimization model that sizes the most cost-efficient renewable power capacity mix of an autonomous microgrid supported by storage technologies.

Simulation tools are employed for assessing operational developments (RES penetration, storage integration, interconnection etc.) within the energy grid. Such tool is the Dispa-SET [21], mainly developed within the Joint Research Centre of the EU Commission, in close collaboration with the University of Liège and the KU Leuven (Belgium) and is focused on the balancing and flexibility problems in European grids. Other tools used in previous work for the Cyprus model were the PLEXOS, DigSILENT, OSeMOSYS, custom-made tools in Matlab, and MESSAGE while currently, IRENA FlexTool is under evaluation.

This work utilizes the Dispa-SET tool and investigates various scenarios for integrating energy storage solutions in the Cyprus energy network while achieving a high degree of RES penetration. All scenarios are aligned to the existing NECP of Cyprus (Jan. 2020), providing further insight on the potential of RES penetration to Cyprus' grid and on the benefits associated with coupled RES/storage deployment.

The remainder of this paper is structured as follows: In the following paragraphs, the methodology is first presented along with a brief introduction of the Dispa-SET model, followed by the description of Cyprus' generation system building blocks and the presentation of the scenarios. Based on the preliminary data attained, different scenarios have been investigated, presenting the mid-term RES/storage deployment needed for achieving the NECP goals in terms of electricity energy mix.

\section{Methodology}

As already mentioned, for this work, the Dispa-SET model has been utilized. For the simulation runs to be as accurate as possible, ensuring repeatability of the results, a specific methodology was followed. The approach is presented in Fig. 1.

Data are collected from official sources (i.e. NECP, EAC, TSO website, Ministry of Finance, Statistical Service, IRENA etc.) related to the energy system of Cyprus and technology development costs. Pre-processing involves filtering the collected data while the configuration files are being prepared according to the Dispa-SET template.

Fig. 1 Methodology

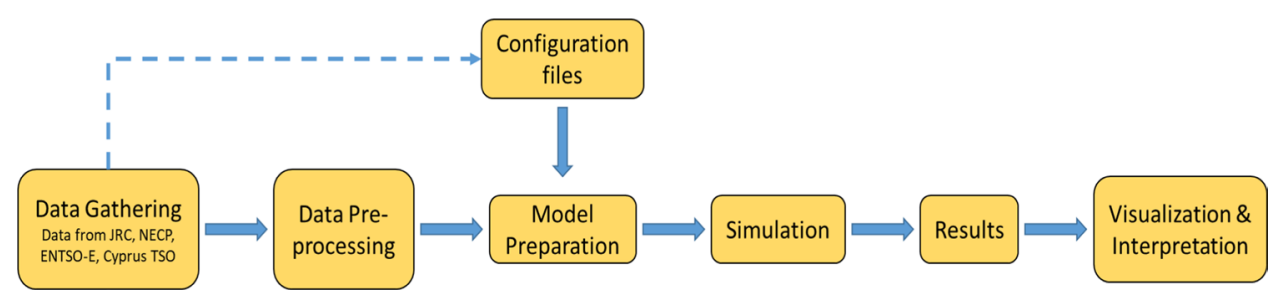




\subsection{Dispa-SET model description}

The Dispa-SET model is developed in GAMS and utilizes csv files for input data handling. For this work, Mixed-Integer Linear Programming has been defined as an optimization method. The model assumes as continuous variables amongst others, the individual unit dispatched power, the shedded load and the curtailed power generation. More details about the model are presented in Ref. [21].

Even though the model has been developed for solving congestion issues on large electricity networks with interconnections of multiple nodes, with the demand side being an aggregated input for each node, while the transmission network is modeled as a transport problem between the nodes, it may well be implemented in isolated grids, such as Cyprus' grid.

The goal is to minimize the total power system costs (expressed in EUR in cost function equation), which are defined as the sum of different cost items, such as start-up and shut-down, fixed, variable, ramping, transmissionrelated and load shedding (voluntary and involuntary) costs, maintenance, etc. The MILP objective function is, therefore, the total generation cost over the optimization period.

The costs can be broken down as:

- Fixed costs,

- Variable costs,

- Start-up costs,

- Shut-down costs,

- Ramp-up,

- Ramp-down,

- Shed load,

- Transmission,

- Loss of load,

- Emission costs (fuel costs),

- Maintenance cost/outage,

- Reserved cost,

- Energy not served.

Some other economic and financial effects, such as job creation, health impacts, opportunity cost etc., are not thoroughly examined since it is out of the scope of this study.

\section{Implementation}

\subsection{Data gathering and pre-processing}

Data related to the Cyprus energy grid as well as the projected targets for the coming decades according to the Cyprus NECP have been collected and pre-processed for use as inputs in the model.

In order to simulate the operation of the power generation system of Cyprus, one has to rely on information of past performance as well as future projections. To this end, past generation and demand data have been collected from TSOC [22] for year 2019, concerning.

(a) Conventional energy generators production (15 min' intervals).

(b) Renewable energy - wind and PV/biomass—production (15 min' intervals).

(c) Demand (15 min' intervals).

Data have been elaborated upon and hourly availability factor profiles have been derived for wind and PV. During 2019, as pointed out in a previous paragraph, wind energy installations have remained unchanged throughout the year, while PVs had a significant increase of $20 \%$. Data of the monthly increase in PV installed capacity have also been 
Fig. 2 Load duration curves

Load-duration curves

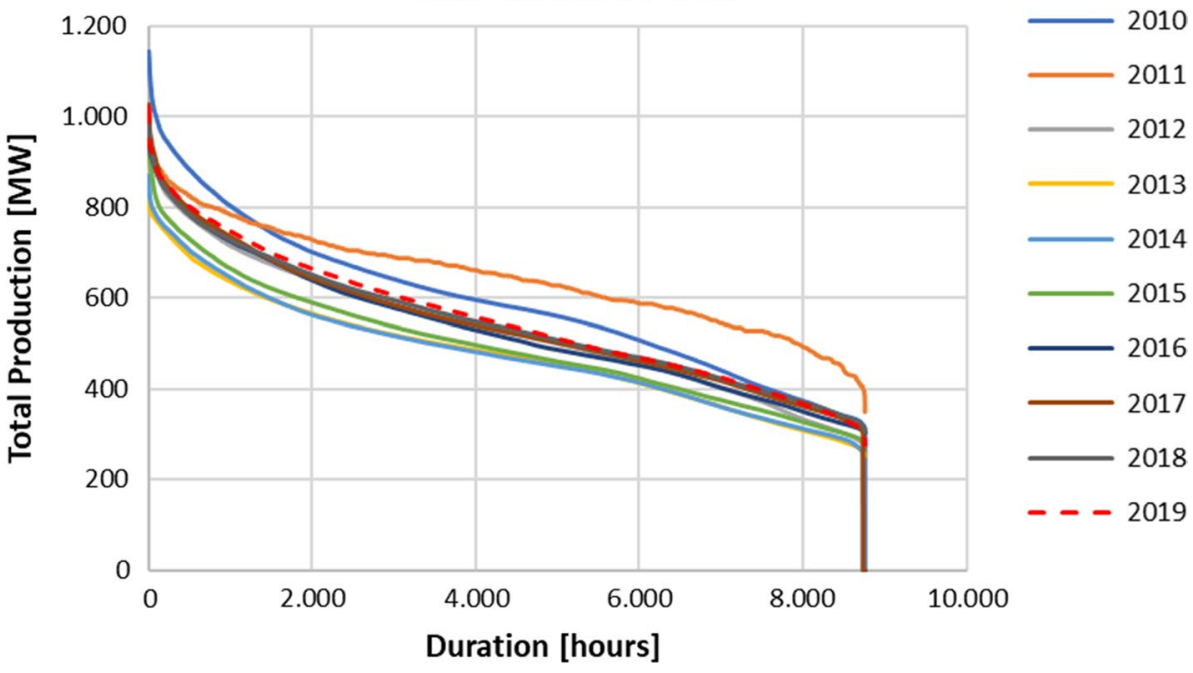

retrieved by TSOC. From TSOC's Load-Duration curve of 2019, shown in the graph bellow (Fig. 2), one may conclude that the 2019 load lies close to 2010-2019 decade mean. As such, it may be regarded as a typical profile to be used also as a reference for future years.

Demand data for 2019 have also been retrieved from ENTSO-E transparency platform [23], which are very similar with the NECP of Cyprus data. Unfortunately, the platform has incomplete or is missing other relevant data for Cyprus, such as generation per unit type, outages, congestion management costs, etc., that are available for other European countries.

Other data sources are the database of typical generators of Dispa-SET, as well as the set of generators and their characteristics already provided for Cyprus in Dispa-SET. These have been used in the simulation of the EU countries' power grid for 2015 by the JRC. More data have been retrieved from the data files of the JRC-EU-TIMES model [24], a scientific tool for assessing the long-term role of energy technologies.

\subsection{Cyprus' electricity generation system}

In addition to the above model, it is essential for one to understand the existing energy system, in this case, the Cyprus energy system. Cyprus has an isolated electricity transmission grid with a power generation system operating in isolation, having to balance demand with generation and in the absence of Storage. The power system relies on imported fuels for electricity generation, mainly heavy fuel oil and, to a lesser extent, gasoil. The main conventional power generators are operated by EAC (Electricity Authority of Cyprus) and are summarized in the Table 1 [25].

The details for each power station regarding their thermal efficiency and their contribution to the island's total energy production are available in the Electricity Authority official website. In addition, the retirement of these units was also taken into account.

Table 1 Cyprus conventional power generators

\begin{tabular}{llllcc}
\hline Power station & Units & Fuel type & Usage & Capacity (MW) & Total (MW) \\
\hline Vasilikos & Steam & HFO & Base load generation & $3 \times 130$ & 390 \\
& Open cycle gas turbine & Diesel & Peak load generation & $1 \times 38$ & 38 \\
& Combined cycle gas turbine & Diesel & Peak load generation & $2 \times 220$ & 440 \\
Dhekelia & Steam & HFO & Base/intermediate load & $6 \times 60$ & 360 \\
& Internal combustion engine & HFO & Peak load generation & $2 \times 50$ & 100 \\
& Open cycle gas turbine & Diesel & Peak load generation & $4 \times 37.5$ & 150 \\
Moni (cold reserve) & Total & & & 1478 \\
& & & &
\end{tabular}


Apart from the conventional power generators there are also RES installations mounting by the end of 2019 at 149.5 MW for PV (124.2 MW by the end of 2018), 12.1 MW biomass (from 9.7 MW by the end of 2018) and 157.5 MW for wind (same as by the end of 2018).

\subsection{Analysis scenarios definition}

For this work, various scenarios have been defined that cover multiple variables affecting the system behavior.

To set up current and future scenarios for the project's analysis, the NECP scenarios for 2030 and 2040 have been considered. The NECP provides projections for the final electricity demand in Cyprus up to the year 2050 (linear interpolation was used from 2030 to 2050). The demand forecast presumes the effect of Existing Measures and Planned Policies and Measures on demand due to energy efficiency measures. The assumptions made during the NECP preparation include among others the updated energy balances of years 2016, 2017 and 2018, the updated list for additional Policies and Measures after 2021, the macroeconomic forecasts of the Ministry of Finance of Cyprus, which were published in September 2018 etc. The forecast is shown in the following figure (see Fig. 3).

According to the latest national report to the European Commission (for the year 2018) [26], the expected future total generated energy for the year 2030 will be as high as $7500 \mathrm{GWh}$, as shown in the following figure, and also used by JRC (JRC-EU-TIMES model) (see Fig. 4).

Future scenarios of generated energy of 7.52 TWh for 2030 and 8.64 TWh for 2040 have been employed for the simulations performed. The National Trends demand profiles are developed from the TSOs input based on latest available member state NECPs. As such, the abovementioned values were calculated as per the TSOC 2019 real profile and scaled for 2030 and 2040 with the 2040 value 15\% larger than 2030. For validation reasons it is noted that demand data used in OseMOSYS simulations (performed on the account of the Ministry) have a demand profile of a total of 7.516 TWh for 2030, close to JRC-EU-TIMES model. Moreover, ENTSO-E TYNDP 2020 Final Scenario national trends demand profiles for Cyprus are at a level of 7.564 TWh for 2030 and 8.515 TWh for 2040.

The revised capacity projections according to the Planned Policies and Measures (PPM) Scenario of NECP is presented in Table 2.

As illustrated in supporting studies for the NECP [4], solar PV is the most competitive of the RET and, as such, is responsible for the increase in renewable energy. Solar capacity increases to a total of $854 \mathrm{MW}$ ( $804 \mathrm{MW}$ PV and $50 \mathrm{MW}$ of (SP) by 2030 comparing with the corresponding 2020 target which is $360 \mathrm{MW}$. The installed capacity as of 10/2021 for comparison reasons mounts to a total of 262.7 MW of Solar PV, 157.5 MW of Wind and 12.4 MW Biomass/Biogas [22], with the PV sector showing good growth dynamics - being quite short, though, from the 2020 projection.

It is evident from Table 2 that analysis done in Ref. [4] for PPM scenario led to the conclusion that no storage facilities will be needed before 2035 to support further penetration of RES and avoid energy curtailment. Table 1 conventional capacity will be diminished by 2025 , since $6 \times 60=360 \mathrm{MW}$ at Dhekelia Power Station (steam turbines) will be decommissioned. Other than that, the rest of the conventional capacity generators will remain in operation at least up to 2030 . For the analysis, the remaining generators are thought to remain more or less the same, since some conventional generating units will be replaced by new conventional units before 2035 and remain active at least till 2040 .

Fig. 3 Forecast of final electricity demand in Cyprus (million kWh)

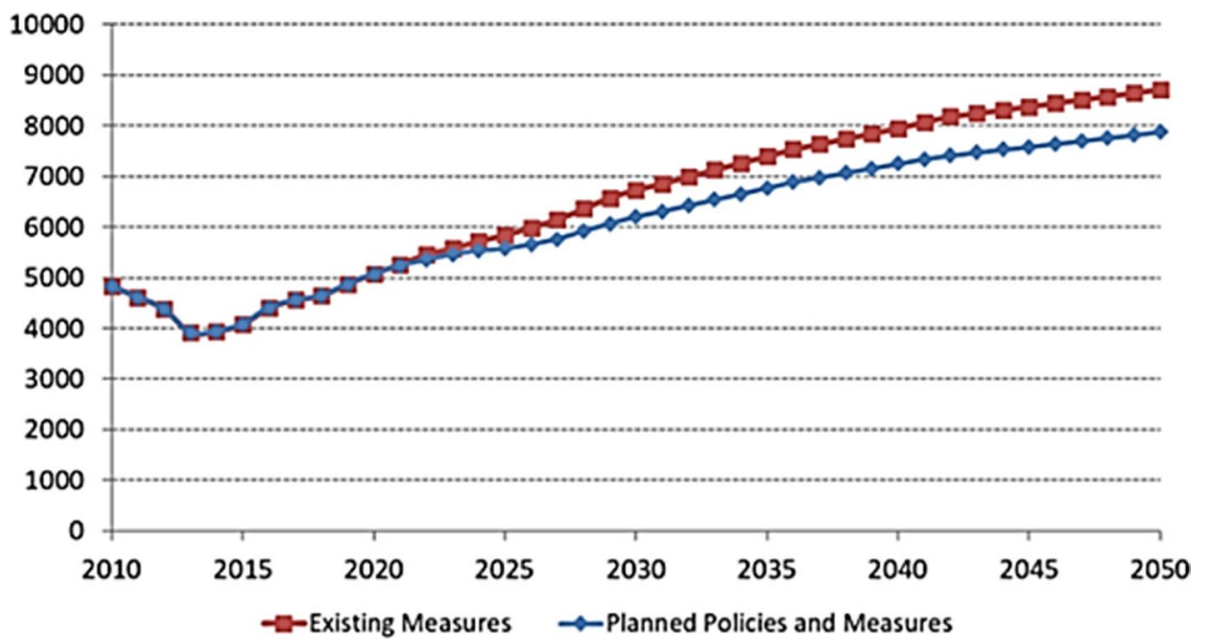




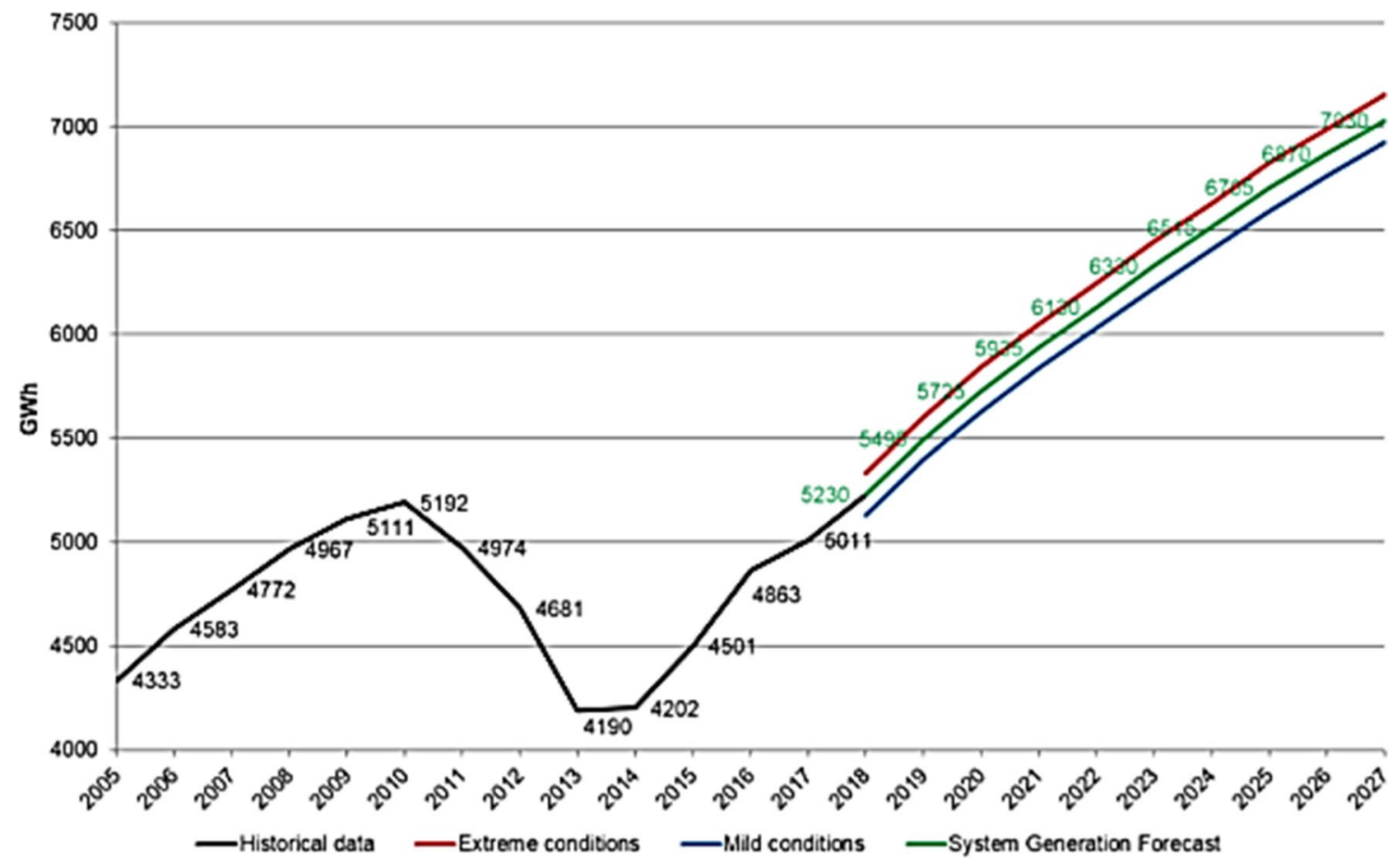

Fig. 4 Expected future total generated energy

Table 2 Capacity projections in the electricity supply sector of Cyprus for PPM scenario [23]

\begin{tabular}{lrrrrrr}
\hline (in MW) & 2020 & 2021 & 2025 & 2030 & 2035 & 2040 \\
\hline New CCGT & 0 & 216 & 432 & 432 & 432 & 648 \\
Solar PV & 360 & 380 & 460 & 840 & 1653 & 1892 \\
Solar thermal & 0 & 0 & 50 & 50 & 50 & 500 \\
Wind & 158 & 158 & 198 & 198 & 198 & 198 \\
Biomass and waste & 17 & 22 & 42 & 58 & 58 & 58 \\
Pumped hydro & 0 & 0 & 0 & 0 & 130 & 130 \\
Li-ion batteries & 0 & 0 & 0 & 0 & 211 & 655 \\
\hline
\end{tabular}

As stated in NECP, the above projections assume ideal market operation since data are not available at present. Moreover, how market forces will distort the predictions cannot be estimated. For the cost optimization to be realized, it is considered that a central operator manages the system with full information on the technical and economic data of the generation units, the demands in each node, and the transmission network. In the case of a wholesale day-ahead power market, the unit commitment problem considered is a simplified instance of the problem faced by the operator in charge of clearing the competitive bids of the participants.

Considering the above information, the scenarios listed in Table 3 have been investigated by employing the Dispa-SET tool to optimize the system's operation.

Scenarios Scen2.1, Scen2.2, Scen2.3 and Scen2.4 are variations of main Scenario Scen2, aiming at providing an insight into whether storage as a whole has any impact on the deployment and use of RES energy. Scen2.1 employs $130 \mathrm{MW}$ pump hydro and $41 \mathrm{MW}$ Li-lon batteries (as in the WEM-with existing measures- scenario of NECP for 2030), as well as an additional $20 \mathrm{MW}$ of hydrogen storage (191 MW in total) as compared to Scen2.2, Scen2.3 and Scen2.4 (each having $171 \mathrm{MW}$ storage). While Scen2.2 to Scen2.4 are variations of Scen2 with the same storage technology for the whole $171 \mathrm{MW}$ capacity, and thus directly comparable to each other, Scen2.1 has a slightly larger capacity, that in effect does not contribute substantially to the system, as can be seen from Table 4. The same stand also for scenario Scen3.1, being a variation of Scen3. Further to the above technical variations, scenarios with varying fuel costs have also been set up. Future scenarios Scen2, Scen3 and Scen3.1 with different fuel price mix were also investigated. Not all production costs 
Table 3 Scenarios parameters

\begin{tabular}{|c|c|c|c|c|c|}
\hline Scenario & Operation year & Simulation target & Technology assumed & Oil price & Gas price \\
\hline Scen 1 & 2019 & Cost effective system operation & As-is & $32.5 € /$ boe & - \\
\hline Scen2 & 2030 & & Table 2 & $32.5 € /$ boe & $50 € /$ boe \\
\hline Scen2p1 & 2030 & & & $49 € /$ boe & $24.50 € /$ boe \\
\hline Scen2p2 & 2030 & & & $40 € /$ boe & $40 € /$ boe \\
\hline Scen2.1 & 2030 & & +3 storage technologies & $32.5 € / \mathrm{boe}$ & $50 € /$ boe \\
\hline Scen2.1p1 & 2030 & & & $49 € /$ boe & $24.50 € /$ boe \\
\hline Scen2.1p2 & 2030 & & & $40 € /$ boe & $40 € /$ boe \\
\hline Scen 2.2 & 2030 & & + Li-ion battery storage & $32.5 € /$ boe & $50 € /$ boe \\
\hline Scen 2.3 & 2030 & & + Pump hydro systems & $32.5 € / \mathrm{boe}$ & $50 € /$ boe \\
\hline Scen 2.4 & 2030 & & + Hydrogen storage & $32.5 € /$ boe & $50 € /$ boe \\
\hline Scen3 & 2040 & & Table 2 & $32.5 € / \mathrm{boe}$ & $50 € /$ boe \\
\hline Scen3p1 & 2040 & & & $49 € /$ boe & $24.50 € /$ boe \\
\hline Scen3p2 & 2040 & & & $40 € /$ boe & $40 € /$ boe \\
\hline Scen3.1 & 2040 & & No storage systems & $32.5 € / \mathrm{boe}$ & $50 € /$ boe \\
\hline Scen3.1p1 & 2040 & & & $49 € /$ boe & $24.50 € /$ boe \\
\hline Scen3.1p2 & 2040 & & & $40 € /$ boe & $40 € /$ boe \\
\hline
\end{tabular}

items have been taken into account. For the present qualitative analysis, the relative effect of fuel prices provides the full envelope and range of prices that covers almost all different forecasts.

One drawback, it that only one oil price is used in Dispa-SET and does not distinguish between HFO and Diesel oil in the same simulation run. The oil prices above represent a price for a mixture oil-HFO price lies around $50-60 \%$ of the price of diesel oil. The price of biomass is estimated and constant at $60 € /$ boe and the $t \mathrm{CO}_{2}$ emission price at $25 € / \mathrm{tCO}_{2}$. The generators (conventional or renewable) and the storage systems and their characteristics are shown in Appendix 1.

\subsection{Assumptions}

The main assumptions made while setting up the Dispa-SET simulation set are the following:

- Isolated system with no interconnections

- No transmission losses considered

- No outage factors for the conventional generators (no pertinent data retrieved, even though Dispa-SET can be fed with hourly profiles)

- Only one "OIL" fuel considered (Dispa-SET has only one OIL as input)

- Fuel prices considered constant throughout the year (even though Dispa-SET can be fed with hourly profiles)

- $\mathrm{CO}_{2}$ cost per tonne equivalent is set the same at $25 € / \mathrm{tCO}_{2}$ for all simulation cases

- No variable (fuel) cost associated with renewables (Wind, PV, Solar Thermal—ST)

- Clustering of units allowed-not interested in particular generator production

- Dispatch of generators to satisfy demand with a horizon of 3 days and 1-day look ahead

- Simulations duration for year y: start at 00:00 h/day1-end at 23:00 h/day 365

- Simulations'implemented time step is $1 \mathrm{~h}$

- No installation, depreciation, or $\mathrm{O}$ and $\mathrm{M}$ costs have been considered

It should be noted that the mathematical problem in order to be solved for a whole year, without becoming extremely demanding in computational terms, is split into smaller optimization problems that are run recursively throughout the year. The optimization horizon is set to three days, with a look-ahead (or overlap) period of one day. The initial values of the optimization for day $j$ are the final values of the optimization of the previous day. The look-ahead period is modelled to avoid issues related to the end of the optimization period such as emptying the hydro reservoirs or starting low-cost but non-flexible power plants. In this case, the optimization is performed over $48 \mathrm{~h}$, but only the first $24 \mathrm{~h}$ are conserved. 


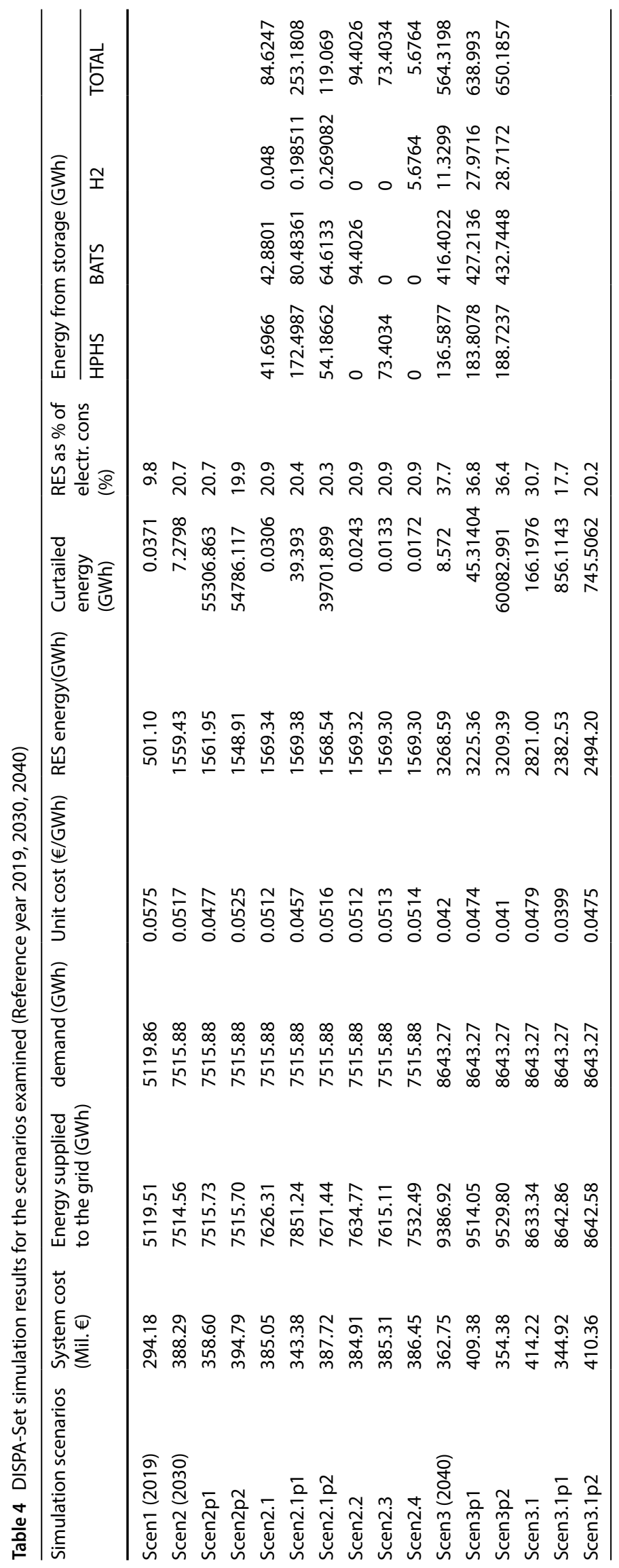


Based on the above-simplified assumptions, System costs correspond to a well-organized system for which ramp-up, ramp-down, start-up, shut-down prices depict the most economical way of operation. Using the above assumptions, soft-calibration model output was done (i.e. compared the expected output results with the OSeMOSYS model actual results for a reference base year and confirmed that the deviation was in the accepted range) with the output of the OseMOSYS model used in NECP for the basic scenario (Scen2) without significant differences.

Some other system characteristics are listed below:

- Peak demand for 2019 mounts to $1034.5 \mathrm{MW}$,

- Peak demand for 2030 is estimated at $1315.8 \mathrm{MW}$,

- Peak demand for 2040 of $1513.2 \mathrm{MW}$ is envisaged.

\section{Results and discussion}

In the graphs within Appendix 2, dispatch for Scen2.1 and Scen3.1 of Par. 4 are indicatively presented for four weeks during the year, namely 15/1-21/1 (winter week), 29/3-30/4 (spring week), 30/6-6/7 (summer week) and 12/10-18/10. The demand profile is also depicted. Similar dispatch profiles have been attained for all scenarios of Table 3.

For cases where storage is considered, the energy consumed for storage (otherwise curtailed) is shown with negative values. The overall System cost and the system unit cost and RES penetration percentage are presented in the table below, summarizing the simulation results.

When evaluating the simulation results, some important outcomes may be pinpointed:

- With the same fuel and other costs, the unit system cost ( $€ / \mathrm{MWh})$ is diminished from Scen1 (2019) to Scen2 (2030) and Scen3 (2040), due to the higher penetration of RES that bare no variable (fuel) cost

- In all the above scenarios for 2030 (Scen2x) RES penetration is well below the target of $26 \%$ energy from renewables in the electricity sector

- More than $4 \%$ of energy is curtailed in 2030 scenarios

- Fuel price variations have little or no effect in RES energy curtailment for 2030, while present significant changes in curtailed RES energy and associated RES penetration for 2040

- Different storage technologies have minimal effect in the overall system cost, while their contribution in RES penetration is not significant. This is because for 2030 in particular in Scen2x RES have limited capacity.

o This conclusion is evident when comparing Scenarios for 2030 with and without storage, without fuel price variations, i.e. Scen2 to Scen2.1, Scen2.2, Scen2.3 and Scen2.4, overall system cost from 388.29 MEuro for Scen2 drops up to 384.91 MEuro with Scen2.2, i.e. a reduction of $<1 \%$. At the same time curtailed energy drops from 7.28 GWh to $13.3-30.6 \mathrm{MWh}$

- On the other hand, increasing RES and storage in Scen2.1s1 and Scen2.1s2 system cost from 385.05 MEuro of Scen2.1 drops to 361.78 MEuro and 354.42 MEuro, respectively, showing a reduction of $6 \%$ and $8 \%$.

- Comparing basic scenario to it's cost variations, it is evident that fuel costs of variation $\mathrm{p} 1$ (i.e. Scen $2 \mathrm{p} 1$ and Scen2.1p1) shows the minimum system cost for the set of scenarios (Scen2-Scen2p1-Scen2p2 and Scen2.1-Scen2.1p1-Scen2.1p2), which is the goal of the minimization simulation

- Variation p2 is the less cost effective, having the most curtailed energy and the less RES penetration, either with or without storage

- Comparing Scen2p1 and Scen2.1p1 together and Scen2p2 and Scen2.1p2 together, one comes to the conclusion that:

- storage with the particular capacities chosen lowers the overall system cost for both fuel price variations, while for p1 price variation lowers

- while the overall system cost reduction is the largest for $\mathrm{p} 1$ variation, also the RES penetration due to increased curtailed energy is lowered

- for $\mathrm{p} 1$ the storage capacity or mix is not optimal in Scen2.1p1, while being close to optimal for Scen2.1, in terms of curtailed energy 
- Due to conclusion (c) above, variations of the storage capacity-Scen2.1s2p1-revealed a far better RES penetration from Scen2.1p1 (27.6\% from 20.4\%) with a much lower overall system cost (312.69 MEuro from 343.38 MEuro), keeping all other parameters the same.

- Evaluating the scenarios for 2040 one can c seems different. For example, for Scen3 and variations p1 and p2, it looks that Scen $3 \mathrm{p} 2$ has the lowest system cost with the more curtailed energy, while for Scen3.1 it seems that Scen3.1 1 has significantly reduced system cost from Scen3.1 and Scen3.1p2 while also having significantly larger curtailed energy and much lower RES penetration. On the other hand, storage reduces curtailment and system cost for all fuel price variation scenarios, apart from system cost for $\mathrm{p} 1$ variation. This again may be attributed to the capacity mix of storage forecasted for 2040 in the simulations

Based on the last findings, further simulation cases have been set up considering more RES (PV in particular) and more storage facilities, in order to check the capacity needed for achieving the goal of $51 \%$ RES-e in the mix for 2030 (26\% RES penetration). The new variation scenarios are presented in the following table (see Table 5).

In the graphs presented in Appendix 3, the dispatch characteristics of Scen $2.1 \mathrm{~s} 2$ are indicatively presented. An overall results matrix and discussion follows in this section.

The table above presents additional scenario variations for 2030 that are described in the following paragraph.

It is evident from Table 6 that for 2030 increasing both PV installed capacity by more than $30 \%$ as compared to Scen 2.1 with accompanied by a corresponding increase in storage capacity as a whole, creates the circumstances where the goal of 2030 for RES penetration can be achieved. For example, for scenario Scen2.1s2, where instead of $804 \mathrm{MW}$ PV and 191 MW Storage in Scen2.1, one has 1125 MW PV and 268 MW storage installed, RES penetration amounts to $27.5 \%$ with a unit system cost reduction of around $6 \%$. Fuel prices, while affecting unit system cost, do not affect RES penetration, as derived from scenarios Scen2.1s2p1 and Scen2.1s $2 \mathrm{p} 2$ results, since LCOE for RES projects with storage seems to be lower than conventional units. The same applies if the storage units were able to install both upstream or downstream of the meter. From the results in Tables 4 and 6 it is depicted that the Energy supplied to the grid is considerably higher than the Energy Demand for the cases with storage. This is due to the fact that storage plays a twin role for demand and supply of electricity. Overall demand is increased due to storage since a certain stored electricity level has to be attained, apart from the fact that storage facilities have losses.

In addition to the above, a validation of the results made using real production data as per the CERA's annual report (for 2019) has been made. Data from CERA's report are presented in Table 7.

In comparison, the optimal RES production by the model for Scen1, which refers to the year 2019, is presented in the table below (see Table 8).

The data retrieved from TSOC mount to a total production for 2019 of 5,119,511 MWh (see Table 4 Scen1, Energy Supply to the grid), i.e. $0.133 \%$ larger than the 5,112,723 MWh given in the CERA report. The RES share from the simulation presented in this work is $9.788 \%$, while the RES share from Table 7 is $9.657 \%$, showing a difference in RES penetration of $+0.131 \%$. It is noted that based on "Assumptions" Section, the OSeMOSYS model was calibrated and validated during the NECP using the same reference production data.

Table 5 New scenarios breakdown

\begin{tabular}{lllcc}
\hline Basic scenario & Oil price & Gas price & Scenario variation 1 & Scenario variation 2 \\
\hline Scen2.1 & Low-32.5€/boe & High-50€/boe & Scen2.1s1 & Scen2.1s2 \\
& & & $30 \%$ more PV capacity & $\begin{array}{c}40 \% \text { more PV } \\
\text { capacity }\end{array}$ \\
& & & $30 \%$ more storage & $40 \%$ more storage \\
Scen2.1s2 & Low-32.5€/boe & High-50€/boe & Scen2.1s2p1 & Scen2.1s2p2 \\
& & & Oil $49 € /$ boe & Oil $40 € /$ boe \\
& & & Gas $24.5 € /$ boe & Gas $40 € /$ boe \\
\hline
\end{tabular}




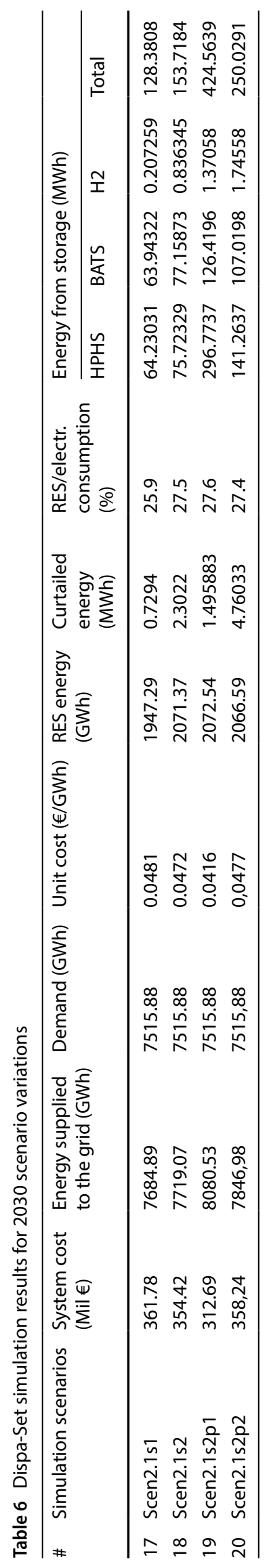


Table 7 Total production data-CERA annual report 2019 [27]

\begin{tabular}{llllll}
\hline Year & $\begin{array}{l}\text { Total production } \\
\text { (Conventional and } \\
\text { RES) (MWh) }\end{array}$ & Wind parks (MWh) & $\begin{array}{l}\text { PV systems } \\
(\mathrm{MWh})\end{array}$ & $\begin{array}{l}\text { Biomass } \\
(\mathrm{MWh})\end{array}$ & $\begin{array}{l}\text { RES total } \\
(\mathrm{MWh})\end{array}$ \\
\hline 2019 & $5,112,723$ & 238,136 & 216,336 & 39,276 & 493,748 \\
& - & $4.7 \%$ & $4.2 \%$ & $0.8 \%$ & $9.657 \%$ \\
\hline
\end{tabular}

Table 8 Scen 1 Optimal RES production (for year 2019)

\begin{tabular}{lllll}
\hline Total production & Wind (MWh) & PV (MWh) & Biomass (MWh) & Total (MWh) \\
\hline $5,119,511$ & 240,798 & 223,074 & 37,230 & 501,102 \\
& & & $9.788 \%$ \\
\hline
\end{tabular}

\section{Summary/conclusions}

From the results presented, only qualitative assumptions can be made from the comparison between test cases. Variations on fuel costs and RES capacity (especially the abundant PV capacity) for future scenarios for 2030 and 2040 revealed so far that RES underlying energy potential may be effectively harvested only by employing storage.

Scenarios for 2030 that achieve the goals set in NECP involve the further deployment of RES (mainly PVs)Scen2.1s2, Scen2.1s2p1, and Scen2.1s2p2 of Table 6.3-as compared to the WEM scenario of the NECP. While energy storage projects could be postponed from 2030 to 2035 or later, assuming that the energy demand will drop below certain thresholds or energy efficiency measures planned will have the same effect on demand, this will not be the case with new RES projects installed. As shown in scenario Scen2.1s2p1, the increased demand and expanded storage and RES penetration will lead to lower system cost. At the same time, the RES Target will be exceeded or have the same effect as the system interconnection.

It is also important to mention that this study did not perform any impact assessment on social and health effects, but based on previous analysis (on similar work done through NECP), it is expected that the results of this scenario will provide more direct and indirect benefits in the long term for Cyprus in all different sectors and sections of the society.

As far as it concerns the electricity interconnector, based on the current NECP results and comparison with the marginal price of the Euroasia interconnector project, [28] it will be lower when compared with Storage technologies. On the other hand, based on the new package for "Fit for 55" and the Carbon Border Adjustment Mechanism, it is expected that prices coming from countries with low RES penetration levels will not be as competitive as before in EU Market Conditions.

Furthermore, the impact of the economy for such measures can be of increased interest since job creation and improvements of quality of life due to better atmospheric conditions and decrease cost in energy supply can lead to the growth of economy and prosperity of Cypriot citizens.

This work can be considered as a continuation of other previous studies of Cyprus performed by IRENA [5], JRC [29, 30], and NECP [4] along with its accompanying studies [31]. CERA has also performed similar analyses for Energy Storage Technologies with emphasis on Battery Storage. Thus the results of both studies can be compared and help the stakeholders make the correct decisions. This work further improves previous results and can provide different future pathways for the island of Cyprus. While Pumped Storage Systems were studied in previous studies, neither of them optimized and analyzed in such detail this technology, which seems to be the most competitive one for the case of Cyprus in the long term.

While batteries' lifetime is usually considered 10 years, Pumped Storage lifetime can exceed 30 years. This period provides a significant advantage for such a system up to 2050 and helps the decarbonization of the island.

The study showed that Cyprus has the advantage that dams are already in place in all its major freshwater streams for freshwater supply purposes, so a part of the required infrastructure exists.

Furthermore, for the first time in long-term planning, this study identifies the introduction of hydrogen in Cyprus energy mix towards the end of the time horizon, which opens the field for further detailed studies. 
Acknowledgements The present study performed in the framework of "Storage and Renewables Electrifying Cyprus" project (SREC, INTEGRATED/0916/0074). SREC project is co-financed by the European Regional Development Fund and the Republic of Cyprus through the Research Innovation Foundation.

Authors' contributions All authors contributed to the preparation of this study. Data gathering was obtained and coordinated by the Ministry of Energy Commerce and Industry (GP, DP, and MI) and CERA. Analyses were performed by AK, DK, GK, and AG. The results and the fine-tuning of the scenarios were discussed with the Ministry. The model was compared with similar models of The Ministry of Energy (calibration was done with GP). GK of Frederick University provided technical consultancy and an overview of the scientific validity of the work. DP wrote the first draft of the manuscript, and all authors commented on previous versions of the manuscript. GP had the overall supervision of the work preparation. Various presentations took place with more than 60 participants demonstrating the results and the scope of the above work. All authors read and approved the final manuscript.

Data availability National Energy and Climate Plan of Cyprus 2020_data available from the corresponding author, upon request.

Code availability Open Source Code using Dispaset Model provided from JRC.

\section{Declarations}

Competing interests The authors declare no competing interests.

Open Access This article is licensed under a Creative Commons Attribution 4.0 International License, which permits use, sharing, adaptation, distribution and reproduction in any medium or format, as long as you give appropriate credit to the original author(s) and the source, provide a link to the Creative Commons licence, and indicate if changes were made. The images or other third party material in this article are included in the article's Creative Commons licence, unless indicated otherwise in a credit line to the material. If material is not included in the article's Creative Commons licence and your intended use is not permitted by statutory regulation or exceeds the permitted use, you will need to obtain permission directly from the copyright holder. To view a copy of this licence, visit http://creativecommons.org/licenses/by/4.0/.

\section{Appendix I}

Scenarios generators and characteristics tables.

Clarification regarding the correspondence of technology presented with the power stations in Table 1 as follows:

\begin{tabular}{|c|l|c|}
\hline Technology & \multicolumn{1}{|c|}{ POWER STATION } & Capacity \\
\hline \multirow{2}{*}{ GTUR } & Moni Open Cycle Gas Turbine & \multirow{2}{*}{$187.5 \mathrm{MW}$} \\
\cline { 2 - 3 } & Vasilikos Open Cycle Gas Turbine & 390 \\
\hline STUR & Vasilikos Steam Turbine & 103.65 \\
\hline ICEN & Dhekelia Internal Combustion Engine & 216 \\
\hline CCCP 1 & Vasilikos Combined Cycle Gas Turbine (CCGT) & 216 \\
\hline CCCP 2 & Vasilikos Combined Cycle Gas Turbine (CCGT) & 432 \\
\hline COMC & New CCGT as per table 2 \\
\hline
\end{tabular}

\section{Scen 1 generators and their characteristics}

\begin{tabular}{|c|c|c|c|c|c|c|c|c|c|c|c|c|c|c|c|}
\hline $\begin{array}{l}\text { Pow- } \\
\text { erca- } \\
\text { pacity } \\
\text { (MW) }\end{array}$ & Type & $\begin{array}{l}\text { Tech- } \\
\text { nology }\end{array}$ & Fuel & $\begin{array}{l}\text { Effi- } \\
\text { ciency } \\
(\% / 100)\end{array}$ & $\begin{array}{l}\text { Min } \\
\text { up } \\
\text { time } \\
\text { (h) }\end{array}$ & $\begin{array}{l}\text { Min } \\
\text { down } \\
\text { time } \\
\text { (h) }\end{array}$ & $\begin{array}{l}\text { Ramp } \\
\text { up } \\
\text { rate } \\
\text { (\%/ } \\
\text { min) }\end{array}$ & $\begin{array}{l}\text { Ramp } \\
\text { down } \\
\text { rate } \\
\text { (\%/ } \\
\text { min) }\end{array}$ & $\begin{array}{l}\text { Start } \\
\text { up cost } \\
\text { (Euro) }\end{array}$ & $\begin{array}{l}\text { No load } \\
\text { cost } \\
\text { (Euro/h) }\end{array}$ & $\begin{array}{l}\text { Ramp- } \\
\text { ing } \\
\text { cost } \\
\text { (Euro/ } \\
\text { MW) }\end{array}$ & $\begin{array}{l}\text { Part } \\
\text { load } \\
\min \\
(\% / 100)\end{array}$ & $\begin{array}{l}\text { Min effi- } \\
\text { ciency } \\
(\% / 100)\end{array}$ & $\begin{array}{l}\text { Start } \\
\text { up } \\
\text { time } \\
\text { (h) }\end{array}$ & $\begin{array}{l}\mathrm{CO} 2 \\
\text { inten- } \\
\text { sity } \\
\text { (tCO2/ } \\
\mathrm{MWh})\end{array}$ \\
\hline 37.5 & Fossil gas & GTUR & OIL & 0.306 & & & 0.133 & 0.133 & 2500 & 240 & 0 & 0.106 & 0.152 & 0 & 0.79 \\
\hline 37.5 & Fossil gas & GTUR & OIL & 0.306 & & & 0.133 & 0.133 & 2500 & 240 & 0 & 0.106 & 0.152 & 0 & 0.79 \\
\hline 37.5 & Fossil gas & GTUR & OIL & 0.306 & & & 0.133 & 0.133 & 2500 & 240 & 0 & 0.106 & 0.152 & 0 & 0.79 \\
\hline 37.5 & Fossil gas & GTUR & OIL & 0.306 & & & 0.133 & 0.133 & 2500 & 240 & 0 & 0.106 & 0.152 & 0 & 0.79 \\
\hline
\end{tabular}




\begin{tabular}{|c|c|c|c|c|c|c|c|c|c|c|c|c|c|c|c|}
\hline $\begin{array}{l}\text { Pow- } \\
\text { erca- } \\
\text { pacity } \\
\text { (MW) }\end{array}$ & Type & $\begin{array}{l}\text { Tech- } \\
\text { nology }\end{array}$ & Fuel & $\begin{array}{l}\text { Effi- } \\
\text { ciency } \\
(\% / 100)\end{array}$ & $\begin{array}{l}\text { Min } \\
\text { up } \\
\text { time } \\
\text { (h) }\end{array}$ & $\begin{array}{l}\text { Min } \\
\text { down } \\
\text { time } \\
\text { (h) }\end{array}$ & $\begin{array}{l}\text { Ramp } \\
\text { up } \\
\text { rate } \\
\text { (\%/ } \\
\text { min) }\end{array}$ & $\begin{array}{l}\text { Ramp } \\
\text { down } \\
\text { rate } \\
\text { (\%/ } \\
\text { min) }\end{array}$ & $\begin{array}{l}\text { Start } \\
\text { up cost } \\
\text { (Euro) }\end{array}$ & $\begin{array}{l}\text { No load } \\
\text { cost } \\
\text { (Euro/h) }\end{array}$ & $\begin{array}{l}\text { Ramp- } \\
\text { ing } \\
\text { cost } \\
\text { (Euro/ } \\
\text { MW) }\end{array}$ & $\begin{array}{l}\text { Part } \\
\text { load } \\
\text { min } \\
(\% / 100)\end{array}$ & $\begin{array}{l}\text { Min effi- } \\
\text { ciency } \\
(\% / 100)\end{array}$ & $\begin{array}{l}\text { Start } \\
\text { up } \\
\text { time } \\
\text { (h) }\end{array}$ & $\begin{array}{l}\mathrm{CO} 2 \\
\text { inten- } \\
\text { sity } \\
\text { (tCO2/ } \\
\text { MWh) }\end{array}$ \\
\hline 60 & Fossil gas & STUR & OIL & 0.316 & & & 0.025 & 0.033 & 10,000 & 30 & 0 & 0.483 & 0.287 & 0 & 0.79 \\
\hline 60 & Fossil gas & STUR & OIL & 0.316 & & & 0.025 & 0.033 & 10,000 & 30 & 0 & 0.483 & 0.287 & 0 & 0.79 \\
\hline 60 & Fossil gas & STUR & OIL & 0.316 & & & 0.025 & 0.033 & 10,000 & 30 & 0 & 0.483 & 0.287 & 0 & 0.79 \\
\hline 60 & Fossil gas & STUR & OIL & 0.316 & & & 0.025 & 0.033 & 10,000 & 30 & 0 & 0.483 & 0.287 & 0 & 0.79 \\
\hline 60 & Fossil gas & STUR & OIL & 0.316 & & & 0.025 & 0.033 & 10,000 & 30 & 0 & 0.483 & 0.287 & 0 & 0.79 \\
\hline 60 & Fossil gas & STUR & OIL & 0.316 & & & 0.025 & 0.033 & 10,000 & 30 & 0 & 0.483 & 0.287 & 0 & 0.79 \\
\hline 17.48 & $\begin{array}{l}\text { Internal } \\
\text { combus- } \\
\text { tion } \\
\text { engine }\end{array}$ & ICEN & OIL & 0.421 & & & 0.057 & 0.057 & 1200 & 85 & 0 & 0.858 & 0.406 & 0 & 0.79 \\
\hline 17.48 & $\begin{array}{l}\text { Internal } \\
\text { combus- } \\
\text { tion } \\
\text { engine }\end{array}$ & ICEN & OIL & 0.421 & & & 0.057 & 0.057 & 1200 & 85 & 0 & 0.858 & 0.406 & 0 & 0.79 \\
\hline 17.48 & $\begin{array}{l}\text { Internal } \\
\text { combus- } \\
\text { tion } \\
\text { engine }\end{array}$ & ICEN & OIL & 0.421 & & & 0.057 & 0.057 & 1200 & 85 & 0 & 0.858 & 0.406 & 0 & 0.79 \\
\hline 17.07 & $\begin{array}{l}\text { Internal } \\
\text { combus- } \\
\text { tion } \\
\text { engine }\end{array}$ & ICEN & OIL & 0.421 & & & 0.059 & 0.059 & 600 & 85 & 0 & 0.879 & 0.406 & 0 & 0.79 \\
\hline 17.07 & $\begin{array}{l}\text { Internal } \\
\text { combus- } \\
\text { tion } \\
\text { engine }\end{array}$ & ICEN & OIL & 0.421 & & & 0.059 & 0.059 & 600 & 85 & 0 & 0.879 & 0.406 & 0 & 0.79 \\
\hline 17.07 & $\begin{array}{l}\text { Internal } \\
\text { combus- } \\
\text { tion } \\
\text { engine }\end{array}$ & ICEN & OIL & 0.421 & & & 0.059 & 0.059 & 600 & 85 & 0 & 0.879 & 0.406 & 0 & 0.79 \\
\hline 130 & Fossil gas & STUR & OIL & 0.401 & & & 0.028 & 0.028 & 20,000 & 60 & 0 & 0.444 & 0.368 & 0 & 0.79 \\
\hline 130 & Fossil gas & STUR & OIL & 0.401 & & & 0.028 & 0.028 & 20,000 & 60 & 0 & 0.444 & 0.368 & 0 & 0.79 \\
\hline 130 & Fossil gas & STUR & OIL & 0.4012 & & & 0.028 & 0.028 & 20,000 & 60 & 0 & 0.444 & 0.368 & 0 & 0.79 \\
\hline 37,5 & Fossil gas & GTUR & OIL & 0.306 & & & 0.133 & 0.133 & 2500 & 240 & 0 & 0.106 & 0.152 & 0 & 0.79 \\
\hline 216 & Fossil gas & COMC & OIL & 0.487 & 6 & & 0.027 & 0.027 & 17,500 & 870 & 0 & 0.273 & 0.479 & 0 & 0.79 \\
\hline 216 & Fossil gas & COMC & OIL & 0.487 & 6 & & 0.027 & 0.027 & 17,500 & 870 & 0 & 0.273 & 0.479 & 0 & 0.79 \\
\hline 157.5 & $\begin{array}{l}\text { Wind } \\
\text { onshore }\end{array}$ & WTON & WIN & 1 & 0 & 0 & 0.108 & 0.108 & 0 & 0 & 0 & 0.000 & 1.000 & 0 & 0 \\
\hline 135.78 & $\begin{array}{l}\text { Photovol- } \\
\text { taic }\end{array}$ & PHOT & SUN & 1 & 0 & 0 & 0.305 & 0.305 & 0 & 0 & 0 & 0.000 & 1.000 & 0 & 0 \\
\hline 12.1 & $\begin{array}{c}\text { biomass/ } \\
\text { biogas }\end{array}$ & STUR & $\mathrm{BIO}$ & 0.46 & 4 & 6 & 0.020 & 0.020 & 120 & 12.5 & 1.3 & 0.350 & 0.350 & 1 & 0 \\
\hline
\end{tabular}




\section{Scen2 generators and their characteristics}

\begin{tabular}{|c|c|c|c|c|c|c|c|c|c|c|c|c|c|c|c|}
\hline $\begin{array}{l}\text { Power } \\
\text { Capacity } \\
{[\mathrm{MW}]}\end{array}$ & Type & Technology & Fuel & $\begin{array}{l}\text { Efficiency } \\
{[\% / 100]}\end{array}$ & $\begin{array}{l}\text { Min Up } \\
\text { Time [h] }\end{array}$ & $\begin{array}{l}\text { Min Down } \\
\text { Time [h] }\end{array}$ & \begin{tabular}{|l} 
Ramp Up \\
Rate \\
{$[\% / \mathrm{min}]$}
\end{tabular} & $\begin{array}{l}\text { Ramp Down } \\
\text { Rate } \\
{[\% / \mathrm{min}]}\end{array}$ & \begin{tabular}{|l} 
Start Up \\
Cost \\
[Euro]
\end{tabular} & \begin{tabular}{|l|} 
No Load \\
Cost \\
[Euro/h]
\end{tabular} & $\begin{array}{l}\text { Ramping } \\
\text { Cost } \\
\text { [Euro/MW] }\end{array}$ & \begin{tabular}{|l|} 
Part Load \\
Min \\
{$[\% / 100]$}
\end{tabular} & $\begin{array}{l}\text { Min } \\
\text { Efficiency } \\
{[\% / 100]}\end{array}$ & $\begin{array}{l}\text { Start Up } \\
\text { Time [h] }\end{array}$ & $\begin{array}{l}\mathrm{CO} 2 \text { Intensity } \\
\text { [tCO2/MWh] }\end{array}$ \\
\hline 37,5 & Fossil Gas & GTUR & OIL & 0,306 & 0 & 0 & 0,13333 & 0,13333 & 2500 & 240 & 0 & 0,106 & 0,1522 & 0 & 0,79 \\
\hline 37,5 & Fossil Gas & GTUR & OIL & 0,306 & 0 & 0 & 0,13333 & 0,13333 & 2500 & 240 & 0 & 0,106 & 0,1522 & 0 & 0,79 \\
\hline 37,5 & Fossil Gas & GTUR & OIL & 0,306 & 0 & 0 & 0,13333 & 0,13333 & 2500 & 240 & 0 & 0,106 & 0,1522 & 0 & 0,79 \\
\hline 37,5 & Fossil Gas & GTUR & OIL & 0,306 & 0 & 0 & 0,13333 & 0,13333 & 2500 & 240 & 0 & 0,106 & 0,1522 & 0 & 0,79 \\
\hline 0 & Fossil Gas & STUR & OIL & 0,316 & 0 & 0 & 0,025 & 0,0333 & 10000 & 30 & 0 & 0,4833 & 0,2867 & 0 & 0,79 \\
\hline 0 & Fossil Gas & STUR & OIL & 0,316 & 0 & 0 & 0,025 & 0,0333 & 10000 & 30 & 0 & 0,4833 & 0,2867 & 0 & 0,79 \\
\hline 0 & Fossil Gas & STUR & OIL & 0,316 & 0 & 0 & 0,025 & 0,0333 & 10000 & 30 & 0 & 0,4833 & 0,2867 & 0 & 0,79 \\
\hline 0 & Fossil Gas & STUR & OIL & 0,316 & 0 & 0 & 0,025 & 0,0333 & 10000 & 30 & 0 & 0,4833 & 0,2867 & 0 & 0,79 \\
\hline 0 & Fossil Gas & STUR & OIL & 0,316 & 0 & 0 & 0,025 & 0,0333 & 10000 & 30 & 0 & 0,4833 & 0,2867 & 0 & 0,79 \\
\hline 0 & Fossil Gas & STUR & OIL & 0,316 & 0 & 0 & 0,025 & 0,0333 & 10000 & 30 & 0 & 0,4833 & 0,2867 & 0 & 0,79 \\
\hline 17,48 & Internal Combustion & ICEN & OIL & 0,421 & 0 & 0 & 0,0572 & 0,0572 & 1200 & 85 & 0 & 0,8581 & 0,4063 & 0 & 0,79 \\
\hline 17,48 & Internal Combustion & AICEN & OIL & 0,421 & 0 & 0 & 0,0572 & 0,0572 & 1200 & 85 & 0 & 0,8581 & 0,4063 & 0 & 0,79 \\
\hline 17,48 & Internal Combustion & AICEN & OIL & 0,421 & 0 & 0 & 0,0572 & 0,0572 & 1200 & 85 & 0 & 0,8581 & 0,4063 & 0 & 0,79 \\
\hline 17,07 & Internal Combustion & IICEN & OIL & 0,421 & 0 & 0 & 0,0586 & 0,0586 & 600 & 85 & 0 & 0,8787 & 0,4063 & 0 & 0,79 \\
\hline 17,07 & Internal Combustion & IICEN & OIL & 0,421 & 0 & 0 & 0,0586 & 0,0586 & 600 & 85 & 0 & 0,8787 & 0,4063 & 0 & 0,79 \\
\hline 17,07 & Internal Combustion & ICEN & OIL & 0,421 & 0 & 0 & 0,0586 & 0,0586 & 600 & 85 & 0 & 0,8787 & 0,4063 & 0 & 0,79 \\
\hline 130 & Fossil Gas & STUR & OIL & 0,4012 & 0 & 0 & 0,0277 & 0,0277 & 20000 & 60 & 0 & 0,4435 & 0,3676 & 0 & 0,79 \\
\hline 130 & Fossil Gas & STUR & OIL & 0,4012 & 0 & 0 & 0,0277 & 0,0277 & 20000 & 60 & 0 & 0,4435 & 0,3676 & 0 & 0,79 \\
\hline 130 & Fossil Gas & STUR & OIL & 0,4012 & 0 & 0 & 0,0277 & 0,0277 & 20000 & 60 & 0 & 0,4435 & 0,3676 & 0 & 0,79 \\
\hline 37,5 & Fossil Gas & GTUR & OIL & 0,306 & 0 & 0 & 0,1333 & 0,1333 & 2500 & 240 & 0 & 0,106 & 0,1522 & 0 & 0,79 \\
\hline 216 & Fossil Gas & COMC-CCCP1 & OIL & 0,4868 & 6 & 0 & 0,0272727 & 0,027272727 & 17500 & 870 & 0 & 0,272727 & 0,4793 & 0 & 0,79 \\
\hline 216 & Fossil Gas & COMC-СCCP2 & OIL & 0,4868 & 6 & 0 & 0,0272727 & 0,027272727 & 17500 & 870 & 0 & 0,272727 & 0,4793 & 0 & 0,79 \\
\hline 198 & Wind Onshore & WTON & WIN & 1 & 0 & 0 & 0,1080865 & 0,108086469 & 0 & 0 & 0 & 0 & 1 & 0 & 0 \\
\hline 804 & Photovoltaic & PHOT & SUN & 1 & 0 & 0 & 0,3047748 & 0,304774805 & 0 & 0 & 0 & 0 & 1 & 0 & 0 \\
\hline 58 & Biomass/biogas & STUR & $\mathrm{BIO}$ & 0,46 & 4 & 6 & 0,02 & 0,02 & 120 & 12,5 & 1,3 & 0,35 & 0,35 & 1 & 0 \\
\hline 432 & CCGT & COMC & GAS & 0,525 & 5 & 1 & 0,0251577 & 0,025157658 & 112542,1 & 0 & 0 & 0,4 & 0,525 & 1 & 0,45 \\
\hline 50 & SolarThermal & STUR & SUN & 0,25 & 0 & 0 & 0,02 & \begin{tabular}{|r}
0,02 \\
\end{tabular} & 0 & 0 & 0 & 0 & 0,2 & 1 & 0 \\
\hline
\end{tabular}

\section{Scen2.1 generators and their characteristics}

\begin{tabular}{|c|c|c|c|c|c|c|c|c|c|c|c|c|c|c|c|}
\hline $\begin{array}{l}\text { Power } \\
\text { Capacity } \\
{[\mathrm{MW}]}\end{array}$ & Type & Technology & Fuel & $\begin{array}{l}\text { Efficiency } \\
{[\% / 100]}\end{array}$ & \begin{tabular}{|l|} 
Min Up \\
Time [h] \\
\end{tabular} & $\begin{array}{l}\text { Min Down } \\
\text { Time [h] } \\
\end{array}$ & \begin{tabular}{|l} 
Ramp Up \\
Rate \\
{$[\% / \mathrm{min}]$}
\end{tabular} & \begin{tabular}{|l} 
Ramp \\
Down \\
Rate \\
{$[\% / \mathrm{min}]$} \\
\end{tabular} & \begin{tabular}{|l} 
Start Up \\
Cost \\
[Euro]
\end{tabular} & \begin{tabular}{|l|} 
No Load \\
Cost \\
{$[$ Euro/h] } \\
\end{tabular} & \begin{tabular}{|l|} 
Ramping \\
Cost \\
[Euro/MW \\
\end{tabular} & \begin{tabular}{|l|} 
Part Load \\
Min \\
{$[\% / 100]$} \\
\end{tabular} & \begin{tabular}{|l} 
Min \\
Efficiency \\
{$[\% / 100]$} \\
\end{tabular} & \begin{tabular}{|l|} 
Start Up \\
Time [h]
\end{tabular} & $\begin{array}{l}\mathrm{CO} 2 \text { Intensity } \\
\text { [tCO2/MWh] }\end{array}$ \\
\hline 37,5 & Fossil Gas & GTUR & OIL & 0,306 & 0 & 0 & \begin{tabular}{|r|}
0,13333 \\
\end{tabular} & 0,13333 & 2500 & 240 & 0 & 0,106 & 0,1522 & 0 & 0,79 \\
\hline 37,5 & Fossil Gas & GTUR & OIL & 0,306 & 0 & 0 & 0,13333 & 0,13333 & 2500 & 240 & 0 & 0,106 & 0,1522 & 0 & 0,79 \\
\hline 37,5 & Fossil Gas & GTUR & OIL & 0,306 & 0 & 0 & 0,13333 & 0,13333 & 2500 & 240 & 0 & 0,106 & 0,1522 & 0 & 0,79 \\
\hline 37,5 & Fossil Gas & GTUR & OIL & 0,306 & 0 & 0 & 0,13333 & 0,13333 & 2500 & 240 & 0 & 0,106 & 0,1522 & 0 & 0,79 \\
\hline & Fossil Gas & STUR & OIL & 0,316 & 0 & 0 & 0,025 & 0,0333 & 10000 & 30 & 0 & 0,4833 & 0,2867 & 0 & 0,79 \\
\hline & Fossil Gas & STUR & OIL & 0,316 & 0 & 0 & 0,025 & 0,0333 & 10000 & 30 & 0 & 0,4833 & 0,2867 & 0 & 0,79 \\
\hline & Fossil Gas & STUR & OIL & 0,316 & 0 & 0 & 0,025 & 0,0333 & 10000 & 30 & 0 & 0,4833 & 0,2867 & 0 & 0,79 \\
\hline & Fossil Gas & STUR & OIL & 0,316 & 0 & 0 & 0,025 & 0,0333 & 10000 & 30 & 0 & 0,4833 & 0,2867 & 0 & 0,79 \\
\hline & Fossil Gas & STUR & OIL & 0,316 & 0 & 0 & 0,025 & 0,0333 & 10000 & 30 & 0 & 0,4833 & 0,2867 & 0 & 0,79 \\
\hline & Fossil Gas & STUR & OIL & 0,316 & 0 & 0 & 0,025 & 0,0333 & 10000 & 30 & 0 & 0,4833 & 0,2867 & 0 & 0,79 \\
\hline 17,48 & Internal Combustion Engine & ICEN & OIL & 0,421 & 0 & 0 & 0,0572 & 0,0572 & 1200 & 85 & 0 & 0,8581 & 0,4063 & 0 & 0,79 \\
\hline 17,48 & Internal Combustion Engine & ICEN & OIL & 0,421 & 0 & 0 & 0,0572 & 0,0572 & 1200 & 85 & 0 & 0,8581 & 0,4063 & 0 & 0,79 \\
\hline 17,48 & Internal Combustion Engine & ICEN & OIL & 0,421 & 0 & 0 & 0,0572 & 0,0572 & 1200 & 85 & 0 & 0,8581 & 0,4063 & 0 & 0,79 \\
\hline 17,07 & Internal Combustion Engine & ICEN & OIL & 0,421 & 0 & 0 & 0,0586 & 0,0586 & 600 & 85 & 0 & 0,8787 & 0,4063 & 0 & 0,79 \\
\hline 17,07 & Internal Combustion Engine & ICEN & OIL & 0,421 & 0 & 0 & 0,0586 & 0,0586 & 600 & 85 & 0 & 0,8787 & 0,4063 & 0 & 0,79 \\
\hline 17,07 & Internal Combustion Engine & ICEN & OIL & 0,421 & 0 & 0 & 0,0586 & 0,0586 & 600 & 85 & 0 & 0,8787 & 0,4063 & 0 & 0,79 \\
\hline 130 & Fossil Gas & STUR & OIL & 0,4012 & 0 & 0 & 0,0277 & 0,0277 & 20000 & 60 & 0 & 0,4435 & 0,3676 & 0 & 0,79 \\
\hline 130 & Fossil Gas & STUR & OIL & 0,4012 & 0 & 0 & 0,0277 & 0,0277 & 20000 & 60 & 0 & 0,4435 & 0,3676 & 0 & 0,79 \\
\hline 130 & Fossil Gas & STUR & OIL & 0,4012 & 0 & 0 & 0,0277 & 0,0277 & 20000 & 60 & 0 & 0,4435 & 0,3676 & 0 & 0,79 \\
\hline 37,5 & Fossil Gas & GTUR & OIL & 0,306 & 0 & 0 & 0,1333 & 0,1333 & 2500 & 240 & 0 & 0,106 & 0,1522 & 0 & 0,79 \\
\hline 216 & Fossil Gas & COMC-CCCP1 & OIL & 0,4868 & 6 & 0 & 0,0272727 & 0,0272727 & 17500 & 870 & 0 & 0,272727 & 0,4793 & 0 & 0,79 \\
\hline 216 & Fossil Gas & COMC-CCCP2 & $\mathrm{OIL}$ & 0,4868 & 6 & 0 & 0,0272727 & 0,0272727 & 17500 & 870 & 0 & 0,272727 & 0,4793 & 0 & 0,79 \\
\hline 198 & Wind Onshore & WTON & WIN & 1 & 0 & 0 & 0,1080865 & 0,1080865 & 0 & 0 & 0 & 0 & 1 & 0 & 0 \\
\hline 804 & Photovoltaic & PHOT & SUN & 1 & 0 & 0 & 0,3047748 & 0,3047748 & 0 & 0 & 0 & 0 & 1 & 0 & 0 \\
\hline 58 & Biomass/biogas & STUR & $\mathrm{BIO}$ & 0,46 & 4 & 6 & $\begin{array}{r}0,02 \\
\end{array}$ & 0,02 & 120 & 12,5 & 1,3 & 0,35 & 0,35 & 1 & 0 \\
\hline 432 & CCGT & COMC & GAS & 0,525 & 5 & 1 & 0,0251577 & 0,0251577 & 112542,1 & 0 & 0 & 0,4 & 0,525 & 1 & 0,45 \\
\hline 50 & SolarThermal & STUR & SUN & 0,25 & 0 & 0 & 0,02 & 0,02 & 0 & 0 & 0 & 0 & 0,2 & 1 & 0 \\
\hline 130 & HPHS & HPHS & WAT & 0,86 & 0 & 0 & 1,9607843 & 1,9607843 & 0 & 0 & 0 & 0 & 0,86 & 0,3 & 0 \\
\hline 41 & Batteries & BATS & OTH & 0,89 & 0 & 0 & 1 & 1 & 0 & 0 & 0 & 0 & 0,89 & 0 & 0 \\
\hline 20 & HYDROGEN & P2GS & HYD & 0,47 & 0 & 0 & 1 & 1 & 0 & 0 & 0 & 0,15 & 0,47 & 0 & 0 \\
\hline
\end{tabular}




\section{Scen2.2 generators and their characteristics}

\begin{tabular}{|c|c|c|c|c|c|c|c|c|c|c|c|c|c|c|c|}
\hline $\begin{array}{l}\text { Power } \\
\text { Capacity } \\
{[\mathrm{MW}]}\end{array}$ & Type & Technology & Fuel & $\begin{array}{l}\text { Efficiency } \\
{[\% / 100]}\end{array}$ & \begin{tabular}{|l|l} 
Min Up \\
Time [h]
\end{tabular} & \begin{tabular}{|l|} 
Min \\
Down \\
Time [h]
\end{tabular} & $\begin{array}{l}\text { Ramp Up } \\
\text { Rate } \\
{[\% / \mathrm{min}]}\end{array}$ & \begin{tabular}{|l|} 
Ramp \\
Down Rate \\
[\%/min]
\end{tabular} & \begin{tabular}{|l|} 
Start Up \\
Cost \\
[Euro]
\end{tabular} & \begin{tabular}{|l|} 
No Load \\
Cost \\
[Euro/h]
\end{tabular} & \begin{tabular}{|l|} 
Ramping \\
Cost \\
[Euro/MW]
\end{tabular} & \begin{tabular}{|l|} 
Part Load \\
Min \\
{$[\% / 100]$}
\end{tabular} & \begin{tabular}{|l|} 
Min \\
Efficiency \\
[\%/100]
\end{tabular} & $\begin{array}{l}\text { Start Up } \\
\text { Time [h] }\end{array}$ & $\begin{array}{l}\mathrm{CO} \text { Intensity } \\
\text { [tCO2/MWh] }\end{array}$ \\
\hline 37,5 & Fossil Gas & GTUR & OIL & 0,306 & 0 & 0 & 0,13333 & 0,13333 & 2500 & 240 & 0 & 0,106 & \begin{tabular}{|l|l|} 
& 0,1522 \\
\end{tabular} & 0 & 0,79 \\
\hline 37,5 & Fossil Gas & GTUR & OIL & 0,306 & 0 & 0 & 0,13333 & 0,13333 & 2500 & 240 & 0 & 0,106 & 0,1522 & 0 & 0,79 \\
\hline 37,5 & Fossil Gas & GTUR & OIL & 0,306 & 0 & 0 & 0,13333 & 0,13333 & 2500 & 240 & 0 & 0,106 & 0,1522 & 0 & 0,79 \\
\hline 37,5 & Fossil Gas & GTUR & OIL & 0,306 & 0 & 0 & 0,13333 & 0,13333 & 2500 & 240 & 0 & 0,106 & 0,1522 & 0 & 0,79 \\
\hline 0 & Fossil Gas & STUR & OIL & 0,316 & 0 & 0 & 0,025 & 0,0333 & 10000 & 30 & 0 & 0,4833 & 0,2867 & 0 & 0,79 \\
\hline 0 & Fossil Gas & STUR & OIL & 0,316 & 0 & 0 & 0,025 & 0,0333 & 10000 & 30 & 0 & 0,4833 & 0,2867 & 0 & 0,79 \\
\hline 0 & Fossil Gas & STUR & OIL & 0,316 & 0 & 0 & 0,025 & 0,0333 & 10000 & 30 & 0 & 0,4833 & 0,2867 & 0 & 0,79 \\
\hline 0 & Fossil Gas & STUR & OIL & 0,316 & 0 & 0 & 0,025 & 0,0333 & 10000 & 30 & 0 & 0,4833 & 0,2867 & 0 & 0,79 \\
\hline & Fossil Gas & STUR & OIL & 0,316 & 0 & 0 & 0,025 & 0,0333 & 10000 & 30 & 0 & 0,4833 & 0,2867 & 0 & 0,79 \\
\hline 0 & Fossil Gas & STUR & OIL & 0,316 & 0 & 0 & 0,025 & 0,0333 & 10000 & 30 & 0 & 0,4833 & 0,2867 & 0 & 0,79 \\
\hline 17,48 & Internal Combustion Engine & ICEN & OIL & 0,421 & 0 & 0 & 0,0572 & 0,0572 & 1200 & 85 & 0 & 0,8581 & 0,4063 & 0 & 0,79 \\
\hline 17,48 & Internal Combustion Engine & ICEN & OIL & 0,421 & 0 & 0 & 0,0572 & 0,0572 & 1200 & 85 & 0 & 0,8581 & 0,4063 & 0 & 0,79 \\
\hline 17,48 & Internal Combustion Engine & ICEN & OIL & 0,421 & 0 & 0 & 0,0572 & 0,0572 & 1200 & 85 & 0 & 0,8581 & 0,4063 & 0 & 0,79 \\
\hline 17,07 & Internal Combustion Engine & ICEN & OIL & 0,421 & 0 & 0 & 0,0586 & 0,0586 & 600 & 85 & 0 & 0,8787 & 0,4063 & 0 & 0,79 \\
\hline 17,07 & Internal Combustion Engine & ICEN & OIL & 0,421 & 0 & 0 & 0,0586 & 0,0586 & 600 & 85 & 0 & 0,8787 & 0,4063 & 0 & 0,79 \\
\hline 17,07 & Internal Combustion Engine & ICEN & OIL & 0,421 & 0 & 0 & 0,0586 & 0,0586 & 600 & 85 & 0 & 0,8787 & 0,4063 & 0 & 0,79 \\
\hline 130 & Fossil Gas & STUR & OIL & 0,4012 & 0 & 0 & 0,0277 & 0,0277 & 20000 & 60 & 0 & 0,4435 & 0,3676 & 0 & 0,79 \\
\hline 130 & Fossil Gas & STUR & OIL & 0,4012 & 0 & 0 & 0,0277 & 0,0277 & 20000 & 60 & 0 & 0,4435 & 0,3676 & 0 & 0,79 \\
\hline 130 & Fossil Gas & STUR & OIL & 0,4012 & 0 & 0 & 0,0277 & 0,0277 & 20000 & 60 & 0 & 0,4435 & 0,3676 & 0 & 0,79 \\
\hline 37,5 & Fossil Gas & GTUR & OIL & 0,306 & 0 & 0 & 0,1333 & 0,1333 & 2500 & 240 & 0 & 0,106 & 0,1522 & 0 & 0,79 \\
\hline 216 & Fossil Gas & COMC-СCCP & OIL & 0,4868 & 6 & 0 & 0,0272727 & 0,02727273 & 17500 & 870 & 0 & 0,272727 & 0,4793 & 0 & 0,79 \\
\hline 216 & Fossil Gas & COMC-СCCP & OIL & 0,4868 & 6 & 0 & 0,0272727 & 0,02727273 & 17500 & 870 & 0 & 0,272727 & 0,4793 & 0 & 0,79 \\
\hline 198 & Wind Onshore & WTON & WIN & 1 & 0 & 0 & 0,1080865 & 0,10808647 & 0 & 0 & 0 & 0 & 1 & 0 & 0 \\
\hline 804 & Photovoltaic & PHOT & SUN & 1 & 0 & 0 & 0,3047748 & 0,30477481 & 0 & 0 & 0 & 0 & 1 & 0 & 0 \\
\hline 58 & Biomass/biogas & STUR & $\mathrm{BIO}$ & 0,46 & 4 & 6 & 0,02 & 0,02 & 120 & 12,5 & 1,3 & 0,35 & 0,35 & 1 & 0 \\
\hline 432 & CCGT & COMC & GAS & 0,525 & 5 & 1 & 0,0251577 & 0,02515766 & 112542,1 & 0 & 0 & 0,4 & 0,525 & 1 & 0,45 \\
\hline 50 & SolarThermal & STUR & SUN & 0,25 & 0 & 0 & $\begin{array}{l}0,02 \\
\end{array}$ & 0,02 & 0 & 0 & 0 & 0 & 0,2 & 1 & 0 \\
\hline 171 & Batteries & BATS & ОTH & 0,89 & 0 & 0 & 1 & 1 & 0 & 0 & 0 & 0 & 0,89 & 0 & 0 \\
\hline
\end{tabular}

\section{Scen2.3 generators and their characteristics}

\begin{tabular}{|c|c|c|c|c|c|c|c|c|c|c|c|c|c|c|c|}
\hline $\begin{array}{l}\text { Power } \\
\text { Capacity } \\
{[\mathrm{MW}]}\end{array}$ & Type & Technology & Fuel & $\begin{array}{l}\text { Efficiency } \\
{[\% / 100]}\end{array}$ & \begin{tabular}{|l|} 
Min Up \\
Time [h] \\
\end{tabular} & \begin{tabular}{|l} 
Min \\
Down \\
Time [h]
\end{tabular} & \begin{tabular}{|l|} 
Ramp Up \\
Rate \\
{$[\% / \mathrm{min}]$}
\end{tabular} & \begin{tabular}{|l|} 
Ramp \\
Down Rate \\
{$[\% / \mathrm{min}]$}
\end{tabular} & \begin{tabular}{|l|} 
Start Up \\
Cost \\
[Euro]
\end{tabular} & $\begin{array}{l}\text { No Load } \\
\text { Cost } \\
{[\text { Euro/h] }}\end{array}$ & \begin{tabular}{|l|} 
Ramping \\
Cost \\
[Euro/MW]
\end{tabular} & \begin{tabular}{|l|} 
Part Load \\
Min \\
{$[\% / 100]$}
\end{tabular} & \begin{tabular}{|l|} 
Min \\
Efficiency \\
{$[\% / 100]$}
\end{tabular} & \begin{tabular}{|l|} 
Start Up \\
Time [h]
\end{tabular} & $\begin{array}{l}\mathrm{CO} 2 \text { Intensity } \\
\text { [tCO2/MWh] }\end{array}$ \\
\hline 37,5 & Fossil Gas & GTUR & OIL & 0,306 & 0 & 0 & 0,13333 & 0,13333 & 2500 & 240 & 0 & 0,106 & $\begin{array}{l}0,1522 \\
\end{array}$ & 0 & 0,79 \\
\hline 37,5 & Fossil Gas & GTUR & OIL & 0,306 & 0 & 0 & 0,13333 & 0,13333 & 2500 & 240 & 0 & 0,106 & 0,1522 & 0 & 0,79 \\
\hline 37,5 & Fossil Gas & GTUR & OIL & 0,306 & 0 & 0 & 0,13333 & 0,13333 & 2500 & 240 & 0 & 0,106 & 0,1522 & 0 & 0,79 \\
\hline 37,5 & Fossil Gas & GTUR & OIL & 0,306 & 0 & 0 & 0,13333 & 0,13333 & 2500 & 240 & 0 & 0,106 & 0,1522 & 0 & 0,79 \\
\hline 0 & Fossil Gas & STUR & OIL & 0,316 & 0 & 0 & 0,025 & 0,0333 & 10000 & 30 & 0 & 0,4833 & 0,2867 & 0 & 0,79 \\
\hline 0 & Fossil Gas & STUR & OIL & 0,316 & 0 & 0 & 0,025 & 0,0333 & 10000 & 30 & 0 & 0,4833 & 0,2867 & 0 & 0,79 \\
\hline 0 & Fossil Gas & STUR & OIL & 0,316 & 0 & 0 & 0,025 & 0,0333 & 10000 & 30 & 0 & 0,4833 & 0,2867 & 0 & 0,79 \\
\hline 0 & Fossil Gas & STUR & OIL & 0,316 & 0 & 0 & 0,025 & 0,0333 & 10000 & 30 & 0 & 0,4833 & 0,2867 & 0 & 0,79 \\
\hline 0 & Fossil Gas & STUR & OIL & 0,316 & 0 & 0 & 0,025 & 0,0333 & 10000 & 30 & 0 & 0,4833 & 0,2867 & 0 & 0,79 \\
\hline 0 & Fossil Gas & STUR & OIL & 0,316 & 0 & 0 & 0,025 & 0,0333 & 10000 & 30 & 0 & 0,4833 & 0,2867 & 0 & 0,79 \\
\hline 17,48 & Internal Combusti & IICEN & OIL & 0,421 & 0 & 0 & 0,0572 & 0,0572 & 1200 & 85 & 0 & 0,8581 & 0,4063 & 0 & 0,79 \\
\hline 17,48 & Internal Combusti & IICEN & OIL & 0,421 & 0 & 0 & 0,0572 & 0,0572 & 1200 & 85 & 0 & 0,8581 & 0,4063 & 0 & 0,79 \\
\hline 17,48 & Internal Combusti & ICEN & OIL & 0,421 & 0 & 0 & 0,0572 & 0,0572 & 1200 & 85 & 0 & 0,8581 & 0,4063 & 0 & 0,79 \\
\hline \begin{tabular}{|l|}
17,07 \\
\end{tabular} & Internal Combusti & ICEN & OIL & 0,421 & 0 & 0 & 0,0586 & 0,0586 & 600 & 85 & 0 & 0,8787 & 0,4063 & 0 & 0,79 \\
\hline 17,07 & Internal Combusti & IICEN & OIL & 0,421 & 0 & 0 & 0,0586 & 0,0586 & 600 & 85 & 0 & 0,8787 & 0,4063 & 0 & 0,79 \\
\hline 17,07 & Internal Combusti & IICEN & OIL & 0,421 & 0 & 0 & 0,0586 & 0,0586 & 600 & 85 & 0 & 0,8787 & 0,4063 & 0 & 0,79 \\
\hline 130 & Fossil Gas & STUR & OIL & 0,4012 & 0 & 0 & 0,0277 & 0,0277 & 20000 & 60 & 0 & 0,4435 & 0,3676 & 0 & 0,79 \\
\hline 130 & Fossil Gas & STUR & OIL & 0,4012 & 0 & 0 & 0,0277 & 0,0277 & 20000 & 60 & 0 & 0,4435 & 0,3676 & 0 & 0,79 \\
\hline 130 & Fossil Gas & STUR & OIL & 0,4012 & 0 & 0 & 0,0277 & 0,0277 & 20000 & 60 & 0 & 0,4435 & 0,3676 & 0 & 0,79 \\
\hline 37,5 & Fossil Gas & GTUR & OIL & 0,306 & 0 & 0 & 0,1333 & 0,1333 & 2500 & 240 & 0 & 0,106 & 0,1522 & 0 & 0,79 \\
\hline 216 & Fossil Gas & COMC-CCCP1 & OIL & 0,4868 & 6 & 0 & 0,0272727 & 0,02727273 & 17500 & 870 & 0 & 0,272727 & 0,4793 & 0 & 0,79 \\
\hline 216 & Fossil Gas & СОМС-СССР2 & OIL & 0,4868 & 6 & 0 & 0,0272727 & \begin{tabular}{|l|}
0,02727273 \\
\end{tabular} & 17500 & 870 & 0 & 0,272727 & 0,4793 & 0 & 0,79 \\
\hline 198 & Wind Onshore & WTON & WIN & 1 & 0 & 0 & 0,1080865 & 0,10808647 & 0 & 0 & 0 & 0 & 1 & 0 & 0 \\
\hline 804 & Photovoltaic & PHOT & SUN & 1 & 0 & 0 & 0,3047748 & 0,30477481 & 0 & 0 & 0 & 0 & 1 & 0 & 0 \\
\hline 58 & Biomass/biogas & STUR & $\mathrm{BIO}$ & 0,46 & 4 & 6 & 0,02 & \begin{tabular}{|r|}
0,02 \\
\end{tabular} & 120 & 12,5 & 1,3 & 0,35 & 0,35 & 1 & 0 \\
\hline 432 & CCGT & COMC & GAS & 0,525 & 5 & 1 & 0,0251577 & \begin{tabular}{|l|}
0,02515766 \\
\end{tabular} & 112542,1 & 0 & 0 & 0,4 & 0,525 & 1 & 0,45 \\
\hline 50 & SolarThermal & STUR & SUN & 0,25 & 0 & 0 & 0,02 & \begin{tabular}{|r|}
0,02 \\
\end{tabular} & \begin{tabular}{|r|}
0 \\
\end{tabular} & 0 & 0 & 0 & 0,2 & 1 & 0 \\
\hline 171 & HPHS & HPHS & WAT & 0,86 & 0 & 0 & 1,9607843 & \begin{tabular}{|l|}
1,96078431 \\
\end{tabular} & 0 & 0 & 0 & 0 & 0,86 & 0,3 & 0 \\
\hline
\end{tabular}




\section{Scen2.4 generators and their characteristics}

\begin{tabular}{|c|c|c|c|c|c|c|c|c|c|c|c|c|c|c|c|}
\hline \begin{tabular}{|l|} 
Power \\
Capacity \\
{$[$ [MW] }
\end{tabular} & Type & Technology & Fuel & $\begin{array}{l}\text { Efficiency } \\
{[\% / 100]}\end{array}$ & \begin{tabular}{|l|} 
Min Up \\
Time [h]
\end{tabular} & \begin{tabular}{|l|} 
Min Down \\
Time [h] \\
\end{tabular} & \begin{tabular}{|l|} 
Ramp Up \\
Rate \\
{$[\% / \mathrm{min}]$}
\end{tabular} & \begin{tabular}{|l|} 
Ramp \\
Down Rate \\
[\%/min]
\end{tabular} & \begin{tabular}{|l|} 
Start Up \\
Cost \\
[Euro] \\
\end{tabular} & \begin{tabular}{|l|} 
No Load \\
Cost \\
[Euro/h]
\end{tabular} & \begin{tabular}{|l} 
Ramping \\
Cost \\
[Euro/MW]
\end{tabular} & \begin{tabular}{|l|} 
Part Load \\
Min \\
{$[\% / 100]$} \\
\end{tabular} & \begin{tabular}{|l|} 
Min \\
Efficiency \\
{$[\% / 100]$}
\end{tabular} & $\begin{array}{l}\text { Start Up } \\
\text { Time [h] }\end{array}$ & $\begin{array}{l}\mathrm{CO} 2 \text { Intensity } \\
\text { [tCO2/MWh] }\end{array}$ \\
\hline \begin{tabular}{|l|}
37,5 \\
\end{tabular} & Fossil Gas & GTUR & OIL & 0,306 & 0 & 0 & 0,13333 & 0,13333 & \begin{tabular}{|l|l|} 
& 2500 \\
\end{tabular} & 240 & 0 & $\begin{array}{l}0,106 \\
\end{array}$ & 0,1522 & $\begin{array}{ll} & 0 \\
\end{array}$ & 0,79 \\
\hline 37,5 & Fossil Gas & GTUR & OIL & 0,306 & 0 & 0 & 0,13333 & 0,13333 & 2500 & 240 & 0 & 0,106 & 0,1522 & 0 & 0,79 \\
\hline 37,5 & Fossil Gas & GTUR & OIL & 0,306 & 0 & 0 & 0,13333 & 0,13333 & 2500 & 240 & 0 & 0,106 & 0,1522 & 0 & 0,79 \\
\hline 37,5 & Fossil Gas & GTUR & $\mathrm{OIL}$ & 0,306 & 0 & 0 & 0,13333 & 0,13333 & 2500 & 240 & 0 & 0,106 & 0,1522 & 0 & 0,79 \\
\hline 0 & Fossil Gas & STUR & OIL & 0,316 & 0 & 0 & 0,025 & 0,0333 & 10000 & 30 & 0 & 0,4833 & 0,2867 & 0 & 0,79 \\
\hline & Fossil Gas & STUR & OIL & 0,316 & 0 & 0 & 0,025 & 0,0333 & 10000 & 30 & 0 & 0,4833 & 0,2867 & 0 & 0,79 \\
\hline & Fossil Gas & STUR & OIL & 0,316 & 0 & 0 & 0,025 & 0,0333 & 10000 & 30 & 0 & 0,4833 & 0,2867 & 0 & 0,79 \\
\hline & Fossil Gas & STUR & OIL & 0,316 & 0 & 0 & 0,025 & 0,0333 & 10000 & 30 & 0 & 0,4833 & 0,2867 & 0 & 0,79 \\
\hline & Fossil Gas & STUR & OIL & 0,316 & 0 & 0 & 0,025 & 0,0333 & 10000 & 30 & 0 & 0,4833 & 0,2867 & 0 & 0,79 \\
\hline & Fossil Gas & STUR & OIL & 0,316 & 0 & 0 & 0,025 & 0,0333 & 10000 & 30 & 0 & 0,4833 & 0,2867 & 0 & 0,79 \\
\hline 17,48 & 3 Internal Combustion Engine & ICEN & OIL & 0,421 & 0 & 0 & 0,0572 & 0,0572 & 1200 & 85 & 0 & 0,8581 & 0,4063 & 0 & 0,79 \\
\hline 17,48 & Internal Combustion Engine & ICEN & OIL & 0,421 & 0 & 0 & 0,0572 & 0,0572 & 1200 & 85 & 0 & 0,8581 & 0,4063 & 0 & 0,79 \\
\hline 17,48 & Internal Combustion Engine & ICEN & OIL & 0,421 & 0 & 0 & 0,0572 & 0,0572 & 1200 & 85 & 0 & 0,8581 & 0,4063 & 0 & 0,79 \\
\hline 17,07 & Internal Combustion Engine & ICEN & OIL & 0,421 & 0 & 0 & 0,0586 & 0,0586 & 600 & 85 & 0 & 0,8787 & 0,4063 & 0 & 0,79 \\
\hline 17,07 & Internal Combustion Engine & ICEN & OIL & 0,421 & 0 & 0 & 0,0586 & 0,0586 & 600 & 85 & 0 & 0,8787 & 0,4063 & 0 & 0,79 \\
\hline 17,07 & Internal Combustion Engine & ICEN & OIL & 0,421 & 0 & 0 & 0,0586 & 0,0586 & 600 & 85 & 0 & 0,8787 & 0,4063 & 0 & 0,79 \\
\hline 130 & Fossil Gas & STUR & OIL & 0,4012 & 0 & 0 & 0,0277 & 0,0277 & 20000 & 60 & 0 & 0,4435 & 0,3676 & 0 & 0,79 \\
\hline 130 & Fossil Gas & STUR & OIL & 0,4012 & 0 & 0 & 0,0277 & 0,0277 & 20000 & 60 & 0 & 0,4435 & 0,3676 & 0 & 0,79 \\
\hline 130 & Fossil Gas & STUR & OIL & 0,4012 & 0 & 0 & 0,0277 & 0,0277 & 20000 & 60 & 0 & 0,4435 & 0,3676 & 0 & 0,79 \\
\hline 37,5 & Fossil Gas & GTUR & OIL & 0,306 & 0 & 0 & 0,1333 & 0,1333 & 2500 & 240 & 0 & 0,106 & 0,1522 & 0 & 0,79 \\
\hline 216 & Fossil Gas & COMC-CCCP1 & OIL & 0,4868 & 6 & 0 & 0,027272727 & 0,02727273 & 17500 & 870 & 0 & 0,272727 & 0,4793 & 0 & 0,79 \\
\hline 216 & Fossil Gas & COMC-CCCP2 & OIL & 0,4868 & 6 & 0 & 0,027272727 & 0,02727273 & 17500 & 870 & 0 & 0,272727 & 0,4793 & 0 & 0,79 \\
\hline 198 & Wind Onshore & WTON & WIN & 1 & 0 & 0 & 0,108086469 & 0,10808647 & 0 & 0 & 0 & 0 & 1 & 0 & 0 \\
\hline 804 & Photovoltaic & PHOT & SUN & 1 & 0 & 0 & 0,304774805 & 0,30477481 & 0 & 0 & 0 & 0 & 1 & 0 & 0 \\
\hline 58 & Biomass/biogas & STUR & $\mathrm{BIO}$ & 0,46 & 4 & 6 & 0,02 & 0,02 & 120 & 12,5 & 1,3 & 0,35 & 0,35 & 1 & 0 \\
\hline 432 & CCGT & COMC & GAS & 0,525 & 5 & 1 & 0,025157658 & 0,02515766 & 112542,1 & 0 & 0 & 0,4 & 0,525 & 1 & 0,45 \\
\hline 50 & SolarThermal & STUR & SUN & 0,25 & 0 & 0 & 0,02 & 0,02 & 0 & 0 & 0 & 0 & 0,2 & 1 & 0 \\
\hline 171 & HYDROGEN & P2GS & HYD & 0,47 & 0 & 0 & 1 & 1 & 0 & 0 & 0 & 0,15 & 0,47 & 0 & 0 \\
\hline
\end{tabular}

\section{Scen3 generators and their characteristics}

\begin{tabular}{|c|c|c|c|c|c|c|c|c|c|c|c|c|c|c|c|}
\hline $\begin{array}{l}\text { Power } \\
\text { Capacity } \\
{[\mathrm{MW}]}\end{array}$ & Type & Technology & Fuel & $\begin{array}{l}\text { Efficiency } \\
{[\% / 100]}\end{array}$ & $\begin{array}{l}\text { Min Up } \\
\text { Time }[\mathrm{h}]\end{array}$ & $\begin{array}{l}\text { Min Down } \\
\text { Time [h] }\end{array}$ & \begin{tabular}{|l} 
Ramp Up \\
Rate \\
{$[\% / \mathrm{min}]$}
\end{tabular} & \begin{tabular}{|l} 
Ramp \\
Down Rate \\
{$[\% / \mathrm{min}]$}
\end{tabular} & \begin{tabular}{|l} 
Start Up \\
Cost \\
[Euro]
\end{tabular} & \begin{tabular}{|l|} 
No Load \\
Cost \\
[Euro/h]
\end{tabular} & \begin{tabular}{|l} 
Ramping \\
Cost \\
[Euro/MW]
\end{tabular} & \begin{tabular}{|l|} 
Part Load \\
Min \\
{$[\% / 100]$}
\end{tabular} & \begin{tabular}{|l|} 
Min \\
Efficiency \\
{$[\% / 100]$}
\end{tabular} & $\begin{array}{l}\text { Start Up } \\
\text { Time [h] }\end{array}$ & $\begin{array}{l}\text { CO2 Intensity } \\
\text { [tCO2/MWh] }\end{array}$ \\
\hline 37,5 & Fossil Gas & GTUR & OIL & 0,306 & 0 & 0 & 0,13333 & \begin{tabular}{|l|l|} 
& 0,13333 \\
\end{tabular} & \begin{tabular}{|l|l|} 
& 2500 \\
\end{tabular} & 240 & 0 & 0,106 & $\begin{array}{l}0,1522 \\
\end{array}$ & 0 & 0,79 \\
\hline 37,5 & Fossil Gas & GTUR & OIL & 0,306 & 0 & 0 & 0,13333 & 0,13333 & 2500 & 240 & 0 & 0,106 & 0,1522 & 0 & 0,79 \\
\hline 37,5 & Fossil Gas & GTUR & OIL & 0,306 & 0 & 0 & 0,13333 & 0,13333 & 2500 & 240 & 0 & 0,106 & 0,1522 & 0 & 0,79 \\
\hline 37,5 & Fossil Gas & GTUR & OIL & 0,306 & 0 & 0 & 0,13333 & 0,13333 & 2500 & 240 & 0 & 0,106 & 0,1522 & 0 & 0,79 \\
\hline 0 & Fossil Gas & STUR & OIL & 0,316 & 0 & 0 & 0,025 & 0,0333 & 10000 & 30 & 0 & 0,4833 & 0,2867 & 0 & 0,79 \\
\hline 0 & Fossil Gas & STUR & OIL & 0,316 & 0 & 0 & 0,025 & 0,0333 & 10000 & 30 & 0 & 0,4833 & 0,2867 & 0 & 0,79 \\
\hline 0 & Fossil Gas & STUR & OIL & 0,316 & 0 & 0 & 0,025 & 0,0333 & 10000 & 30 & 0 & 0,4833 & 0,2867 & 0 & 0,79 \\
\hline 0 & Fossil Gas & STUR & OIL & 0,316 & 0 & 0 & 0,025 & 0,0333 & 10000 & 30 & 0 & 0,4833 & 0,2867 & 0 & 0,79 \\
\hline 0 & Fossil Gas & STUR & OIL & 0,316 & 0 & 0 & 0,025 & 0,0333 & 10000 & 30 & 0 & 0,4833 & 0,2867 & 0 & 0,79 \\
\hline 0 & Fossil Gas & STUR & OIL & 0,316 & 0 & 0 & 0,025 & 0,0333 & 10000 & 30 & 0 & 0,4833 & 0,2867 & 0 & 0,79 \\
\hline 17,48 & Internal Combustion Engine & ICEN & OIL & 0,421 & 0 & 0 & 0,0572 & 0,0572 & 1200 & 85 & 0 & 0,8581 & 0,4063 & 0 & 0,79 \\
\hline 17,48 & Internal Combustion Engine & ICEN & OIL & 0,421 & 0 & 0 & 0,0572 & 0,0572 & 1200 & 85 & 0 & 0,8581 & 0,4063 & 0 & 0,79 \\
\hline 17,48 & Internal Combustion Engine & ICEN & OIL & 0,421 & 0 & 0 & 0,0572 & 0,0572 & 1200 & 85 & 0 & 0,8581 & 0,4063 & 0 & 0,79 \\
\hline 17,07 & Internal Combustion Engine & ICEN & OIL & 0,421 & 0 & 0 & 0,0586 & 0,0586 & 600 & 85 & 0 & 0,8787 & 0,4063 & 0 & 0,79 \\
\hline 17,07 & Internal Combustion Engine & ICEN & OIL & 0,421 & 0 & 0 & 0,0586 & 0,0586 & 600 & 85 & 0 & 0,8787 & 0,4063 & 0 & 0,79 \\
\hline 17,07 & Internal Combustion Engine & ICEN & OIL & 0,421 & 0 & 0 & 0,0586 & 0,0586 & 600 & 85 & 0 & 0,8787 & 0,4063 & 0 & 0,79 \\
\hline 130 & Fossil Gas & STUR & OIL & 0,4012 & 0 & 0 & 0,0277 & 0,0277 & 20000 & 60 & 0 & 0,4435 & 0,3676 & 0 & 0,79 \\
\hline 130 & Fossil Gas & STUR & OIL & 0,4012 & 0 & 0 & 0,0277 & 0,0277 & 20000 & 60 & 0 & 0,4435 & 0,3676 & 0 & 0,79 \\
\hline 130 & Fossil Gas & STUR & OIL & 0,4012 & 0 & 0 & 0,0277 & 0,0277 & 20000 & 60 & 0 & 0,4435 & 0,3676 & 0 & 0,79 \\
\hline 37,5 & Fossil Gas & GTUR & OIL & 0,306 & 0 & 0 & 0,1333 & 0,1333 & 2500 & 240 & 0 & 0,106 & 0,1522 & 0 & 0,79 \\
\hline 216 & Fossil Gas & СОМС-СССР1 & $\mathrm{OIL}$ & 0,4868 & 6 & 0 & 0,0272727 & 0,0272727 & 17500 & 870 & 0 & 0,272727 & 0,4793 & 0 & 0,79 \\
\hline 216 & Fossil Gas & СОMC-СССР2 & OIL & 0,4868 & 6 & 0 & 0,0272727 & 0,0272727 & 17500 & 870 & 0 & \begin{tabular}{|l|}
0,272727 \\
\end{tabular} & 0,4793 & 0 & 0,79 \\
\hline 198 & Wind Onshore & WTON & WIN & 1 & 0 & 0 & 0,1080865 & 0,1080865 & 0 & 0 & 0 & \begin{tabular}{|l|}
0 \\
\end{tabular} & 1 & 0 & 0 \\
\hline 1892 & Photovoltaic & PHOT & SUN & 1 & 0 & 0 & 0,3047748 & 0,3047748 & 0 & 0 & 0 & 0 & 1 & 0 & 0 \\
\hline 58 & Biomass/biogas & STUR & $\mathrm{BIO}$ & 0,46 & 4 & 6 & 0,02 & 0,02 & 120 & 12,5 & 1,3 & 0,35 & 0,35 & 1 & 0 \\
\hline 648 & CCGT & COMC & GAS & 0,525 & 5 & 1 & 0,0251577 & 0,0251577 & \begin{tabular}{|l|}
112542,1 \\
\end{tabular} & 0 & 0 & 0,4 & 0,525 & 1 & 0,45 \\
\hline 50 & SolarThermal & STUR & SUN & 0,25 & 0 & 0 & 0,02 & 0,02 & 0 & 0 & 0 & 0 & 0,2 & 1 & 0 \\
\hline 130 & HPHS & HPHS & WAT & 0,86 & 0 & 0 & 1,9607843 & 1,9607843 & 0 & 0 & 0 & 0 & 0,86 & 0,3 & 0 \\
\hline 655 & Batteries & BATS & OTH & 0,89 & 0 & 0 & 1 & 1 & 0 & 0 & 0 & 0 & 0,89 & 0 & 0 \\
\hline 100 & HYDROGEN & P2GS & HYD & 0,47 & 0 & 0 & 1 & 1 & 0 & 0 & 0 & 0,15 & 0,47 & 0 & 0 \\
\hline
\end{tabular}




\section{Scen3.1 generators and their characteristics}

\begin{tabular}{|c|c|c|c|c|c|c|c|c|c|c|c|c|c|c|c|}
\hline $\begin{array}{l}\text { Power } \\
\text { Capacity } \\
{[\mathrm{MW}]}\end{array}$ & Type & Technology & Fuel & $\begin{array}{l}\text { Efficiency } \\
\text { [\%/100] }\end{array}$ & \begin{tabular}{|l|} 
Min Up \\
Time [h]
\end{tabular} & $\begin{array}{l}\text { Min Down } \\
\text { Time [h] }\end{array}$ & \begin{tabular}{|l|} 
Ramp Up \\
Rate \\
{$[\% / \mathrm{min}]$} \\
\end{tabular} & \begin{tabular}{|l|} 
Ramp \\
Down \\
Rate \\
{$[\% / \mathrm{min}]$} \\
\end{tabular} & \begin{tabular}{|l|} 
Start Up \\
Cost \\
[Euro]
\end{tabular} & \begin{tabular}{|l} 
No Load \\
Cost \\
[Euro/h]
\end{tabular} & $\begin{array}{l}\text { Ramping } \\
\text { Cost } \\
\text { [Euro/MW] }\end{array}$ & \begin{tabular}{|l|} 
Part Load \\
Min \\
{$[\% / 100]$} \\
\end{tabular} & \begin{tabular}{|l|} 
Min \\
Efficiency \\
{$[\% / 100]$}
\end{tabular} & $\begin{array}{l}\text { Start Up } \\
\text { Time [h] }\end{array}$ & $\begin{array}{l}\text { CO2 } \\
\text { Intensity } \\
\text { [tCO2/MWh] }\end{array}$ \\
\hline 37,5 & Fossil Gas & GTUR & OIL & 0,306 & 0 & 0 & 0,13333 & 0,13333 & 2500 & 240 & 0 & 0,106 & 0,1522 & 0 & 0,79 \\
\hline 37,5 & Fossil Gas & GTUR & OIL & 0,306 & 0 & 0 & 0,13333 & 0,13333 & 2500 & 240 & 0 & 0,106 & 0,1522 & 0 & 0,79 \\
\hline 37,5 & Fossil Gas & GTUR & OIL & 0,306 & 0 & 0 & 0,13333 & 0,13333 & 2500 & 240 & 0 & 0,106 & 0,1522 & 0 & 0,79 \\
\hline 37,5 & Fossil Gas & GTUR & OIL & 0,306 & 0 & 0 & 0,13333 & 0,13333 & 2500 & 240 & 0 & 0,106 & 0,1522 & 0 & 0,79 \\
\hline 0 & Fossil Gas & STUR & OIL & 0,316 & 0 & 0 & 0,025 & 0,0333 & 10000 & 30 & 0 & 0,4833 & 0,2867 & 0 & 0,79 \\
\hline 0 & Fossil Gas & STUR & OIL & 0,316 & 0 & 0 & 0,025 & 0,0333 & 10000 & 30 & 0 & 0,4833 & 0,2867 & 0 & 0,79 \\
\hline 0 & Fossil Gas & STUR & OIL & 0,316 & 0 & 0 & 0,025 & 0,0333 & 10000 & 30 & 0 & 0,4833 & 0,2867 & 0 & 0,79 \\
\hline 0 & Fossil Gas & STUR & OIL & 0,316 & 0 & 0 & 0,025 & 0,0333 & 10000 & 30 & 0 & 0,4833 & 0,2867 & 0 & 0,79 \\
\hline 0 & Fossil Gas & STUR & OIL & 0,316 & 0 & 0 & 0,025 & 0,0333 & 10000 & 30 & 0 & 0,4833 & 0,2867 & 0 & 0,79 \\
\hline 0 & Fossil Gas & STUR & OIL & 0,316 & 0 & 0 & 0,025 & 0,0333 & 10000 & 30 & 0 & 0,4833 & 0,2867 & 0 & 0,79 \\
\hline 17,48 & Internal Combustion Engine & ICEN & OIL & 0,421 & 0 & 0 & 0,0572 & 0,0572 & 1200 & 85 & 0 & 0,8581 & 0,4063 & 0 & 0,79 \\
\hline 17,48 & Internal Combustion Engine & ICEN & OIL & 0,421 & 0 & 0 & 0,0572 & 0,0572 & 1200 & 85 & 0 & 0,8581 & 0,4063 & 0 & 0,79 \\
\hline 17,48 & Internal Combustion Engine & ICEN & OIL & 0,421 & 0 & 0 & 0,0572 & 0,0572 & 1200 & 85 & 0 & 0,8581 & 0,4063 & 0 & 0,79 \\
\hline 17,07 & Internal Combustion Engine & ICEN & OIL & 0,421 & 0 & 0 & 0,0586 & 0,0586 & 600 & 85 & 0 & 0,8787 & 0,4063 & 0 & 0,79 \\
\hline 17,07 & Internal Combustion Engine & ICEN & OIL & 0,421 & 0 & 0 & 0,0586 & 0,0586 & 600 & 85 & 0 & 0,8787 & 0,4063 & 0 & 0,79 \\
\hline 17,07 & Internal Combustion Engine & ICEN & OIL & 0,421 & 0 & 0 & 0,0586 & 0,0586 & 600 & 85 & 0 & 0,8787 & 0,4063 & 0 & 0,79 \\
\hline 130 & Fossil Gas & STUR & OIL & 0,4012 & 0 & 0 & 0,0277 & 0,0277 & 20000 & 60 & 0 & 0,4435 & 0,3676 & 0 & 0,79 \\
\hline 130 & Fossil Gas & STUR & OIL & 0,4012 & 0 & 0 & 0,0277 & 0,0277 & 20000 & 60 & 0 & 0,4435 & 0,3676 & 0 & 0,79 \\
\hline 130 & Fossil Gas & STUR & OIL & 0,4012 & 0 & 0 & 0,0277 & 0,0277 & 20000 & 60 & 0 & 0,4435 & 0,3676 & 0 & 0,79 \\
\hline 37,5 & Fossil Gas & GTUR & OIL & 0,306 & 0 & 0 & 0,1333 & 0,1333 & 2500 & 240 & 0 & 0,106 & 0,1522 & 0 & 0,79 \\
\hline 216 & Fossil Gas & COMC-СCCP1 & OIL & 0,4868 & 6 & 0 & 0,0272727 & 0,0272727 & 17500 & 870 & 0 & 0,272727 & 0,4793 & 0 & 0,79 \\
\hline 216 & Fossil Gas & COMC-CCCP2 & OIL & 0,4868 & 6 & 0 & 0,0272727 & 0,0272727 & 17500 & 870 & 0 & 0,272727 & 0,4793 & 0 & 0,79 \\
\hline 198 & Wind Onshore & WTON & WIN & 1 & 0 & 0 & 0,1080865 & 0,1080865 & 0 & 0 & 0 & 0 & 1 & 0 & 0 \\
\hline 1892 & Photovoltaic & PHOT & SUN & 1 & 0 & 0 & 0,3047748 & 0,3047748 & 0 & 0 & 0 & 0 & 1 & 0 & 0 \\
\hline 58 & Biomass/biogas & STUR & $\mathrm{BIO}$ & 0,46 & 4 & 6 & 0,02 & 0,02 & 120 & 12,5 & 1,3 & 0,35 & 0,35 & 1 & 0 \\
\hline 648 & CCGT & COMC & GAS & 0,525 & 5 & 1 & 0,0251577 & 0,0251577 & 112542,1 & 0 & 0 & 0,4 & 0,525 & 1 & 0,45 \\
\hline 50 & SolarThermal & STUR & SUN & 0,25 & 0 & 0 & 0,02 & 0,02 & 0 & 0 & 0 & 0 & 0,2 & 1 & 0 \\
\hline
\end{tabular}

\section{Appendix 2}

Dispa-SET simulation results graphs-(selection).

\section{Simulation scenarios}

Scen2.1

Scen3.

Scen2.1 - Winter week

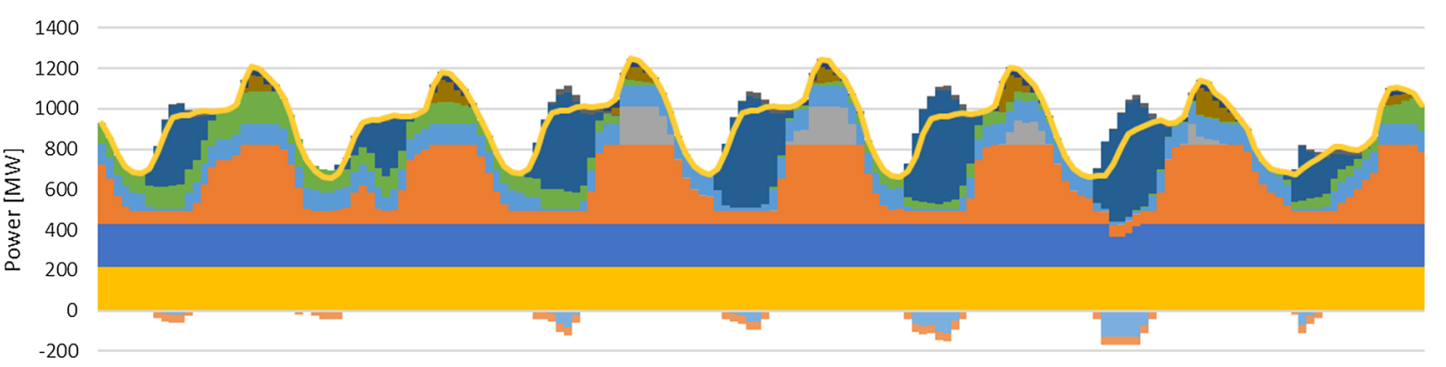

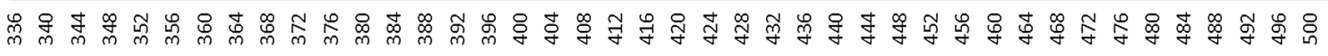
Hour of the year [h]
STORAGE HYDROGEN

STORAGE BATS

STORAGE HPHS

HYDROGEN

BATS

HPHS

ST

$\Longrightarrow \mathrm{PV}$

WIND

New CCGT

ICEN -OIL

GTUR - OIL

STUR - OIL

CCCP2

CCCP1

$\longrightarrow$ DEMAND 
Scen2.1 - Spring week

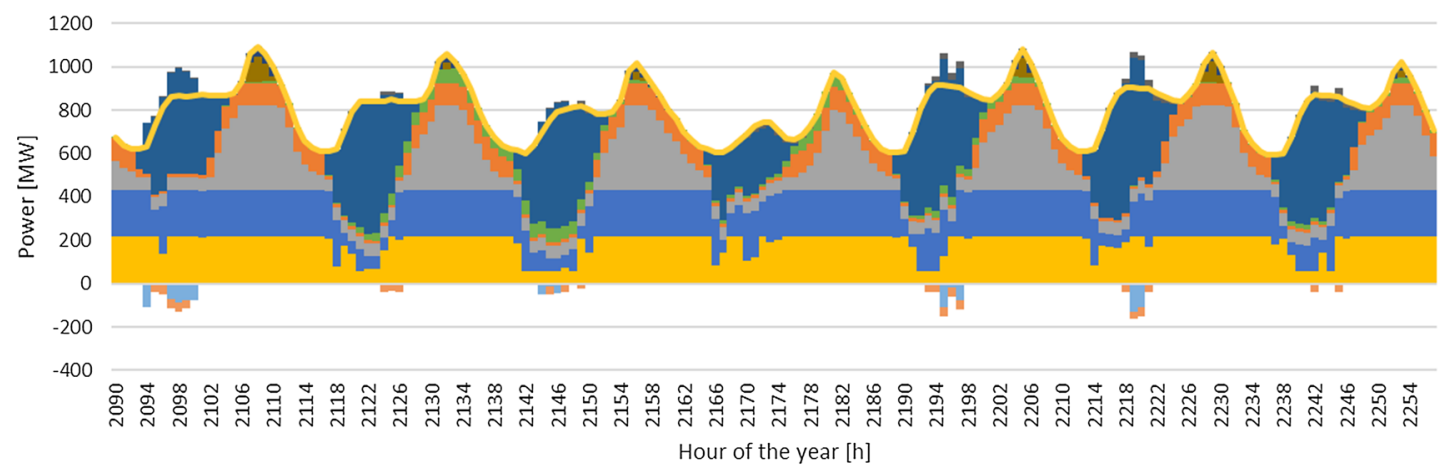
Hour of the year [h]

Scen2.1 - Summer week

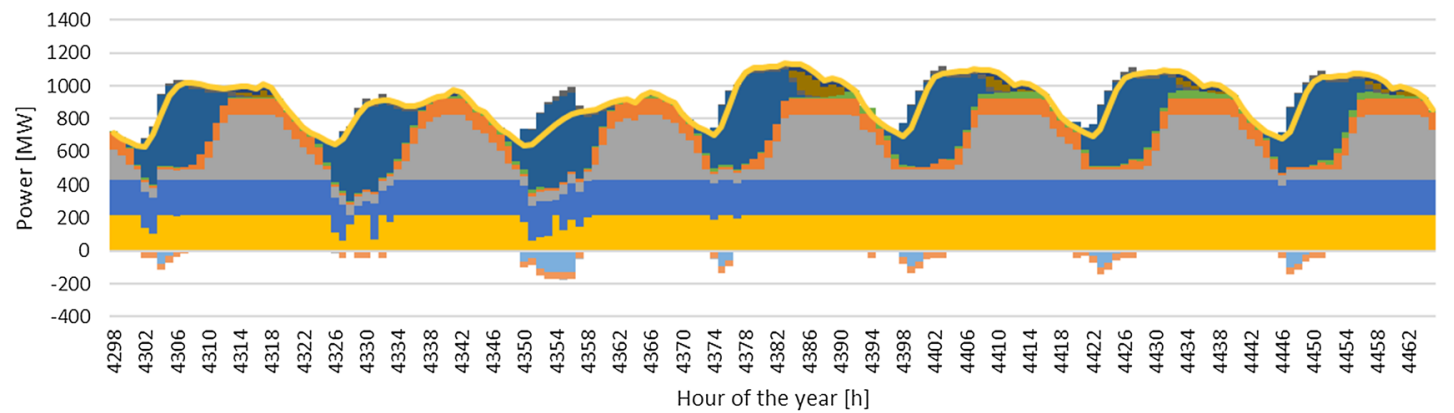

Scen2.1 - Autumn week

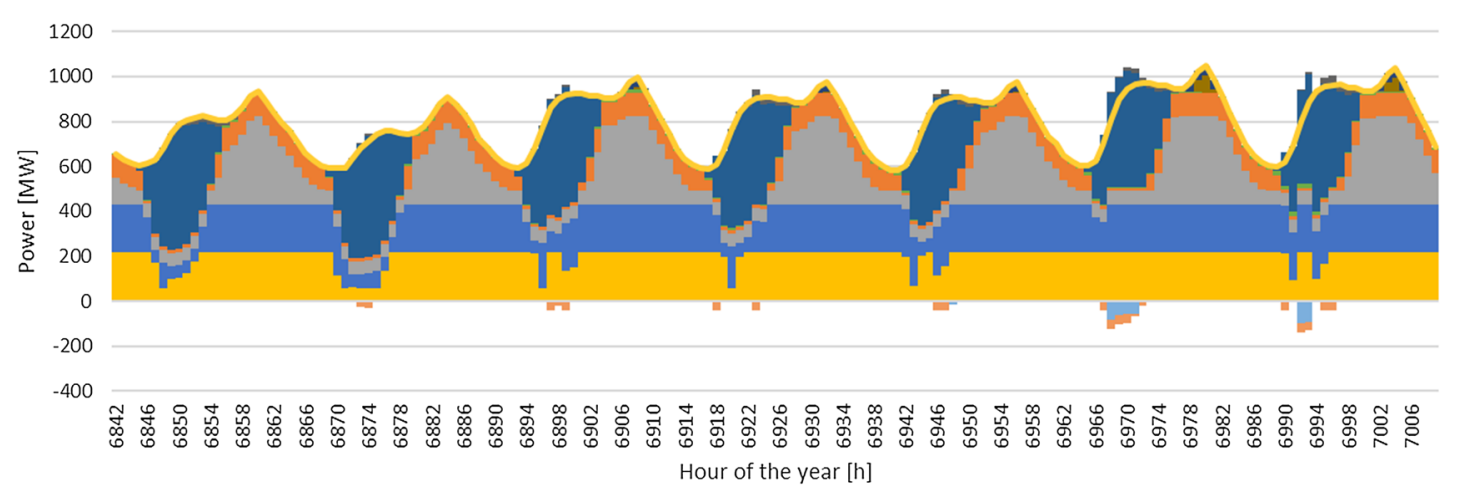

STORAGE HYDROGEN

STORAGE BATS

STORAGE HPHS

HYDROGEN

BATS

HPHS

ST

PV

WIND

New CCGT

ICEN -OIL

GTUR - OIL

STUR - OIL

CCCP2

$=\mathrm{CCCP} 1$

DEMAND

STORAGE HYDROGEN

STORAGE BATS

STORAGE HPHS

HYDROGEN

BATS

HPHS

ST

PV

WIND

New CCGT

ICEN -OIL

GTUR - OII

STUR - OIL

CCCP2

CCCP1

$\longrightarrow$ DEMAND

STORAGE HYDROGEN

STORAGE BATS

STORAGE HPHS

HYDROGEN

BATS

HPHS

ST

PV

WIND

New CCGT

ICEN -OIL

GTUR - OIL

STUR - OIL

CCCP2

CCCP1

DEMAND 

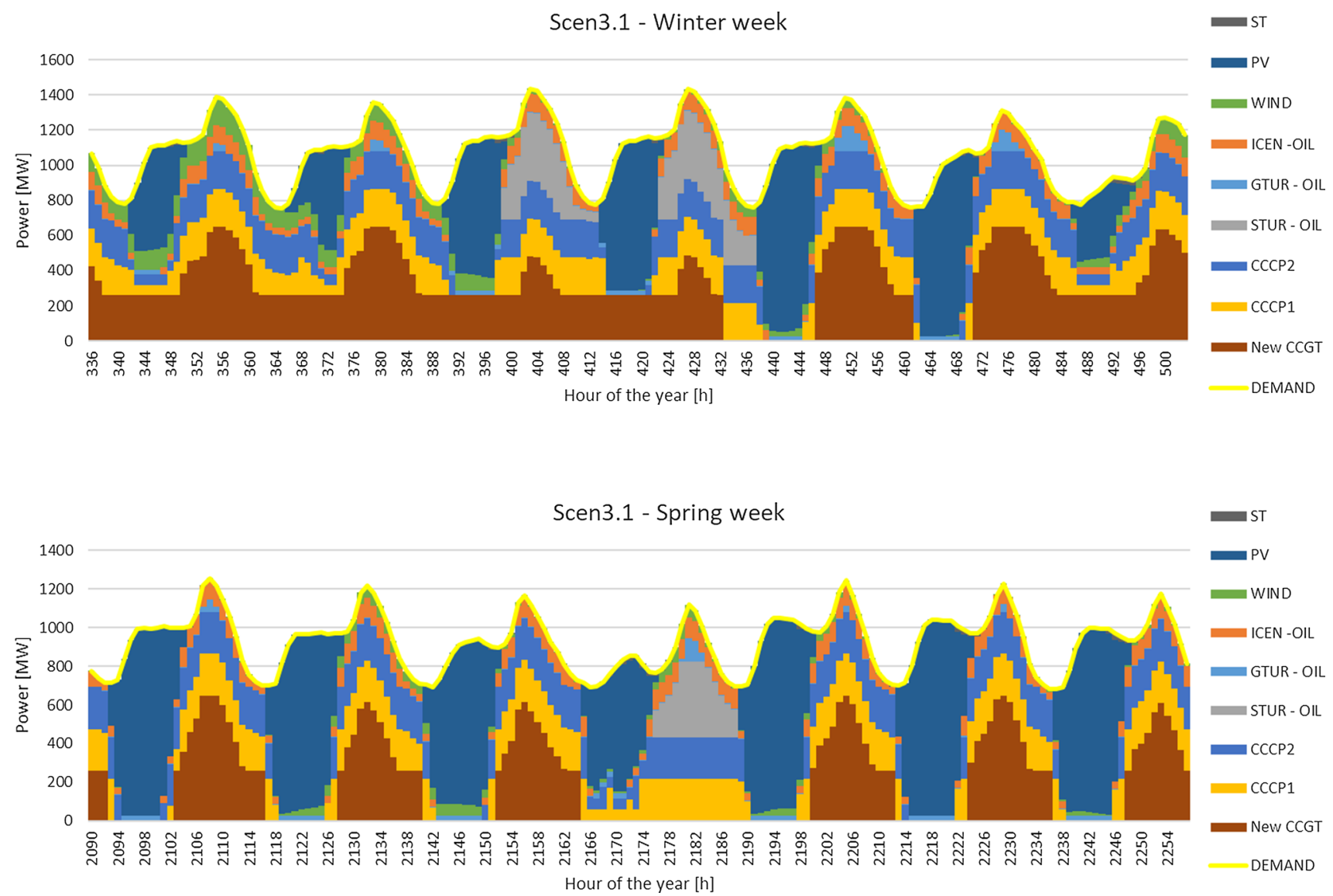
Hour of the year [h]

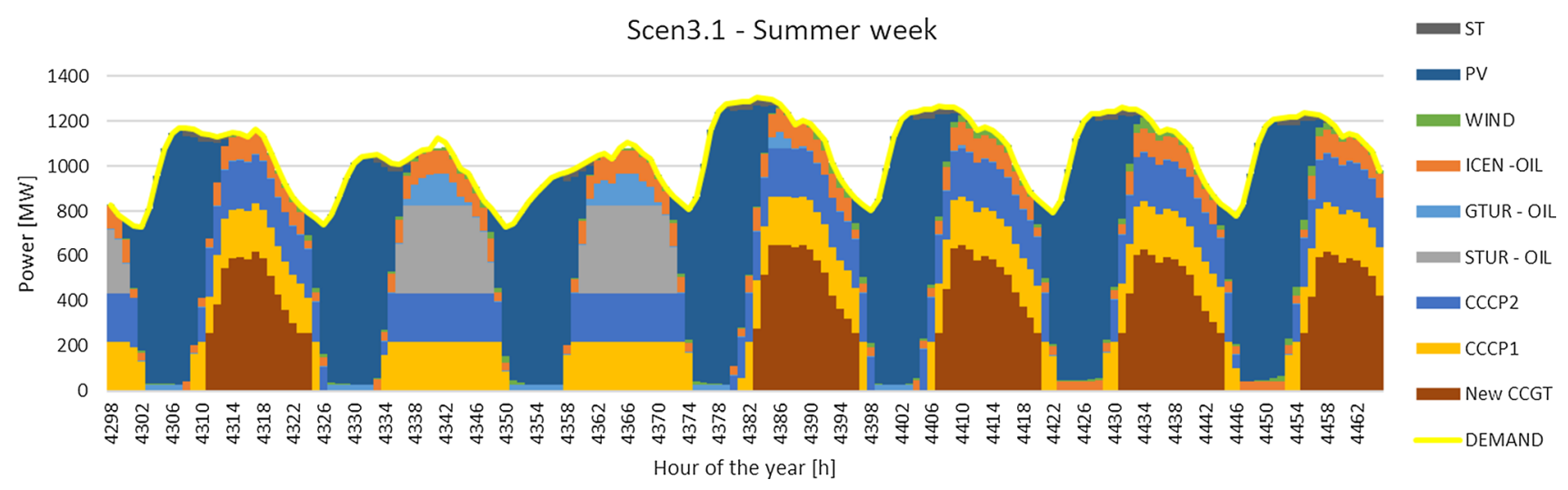




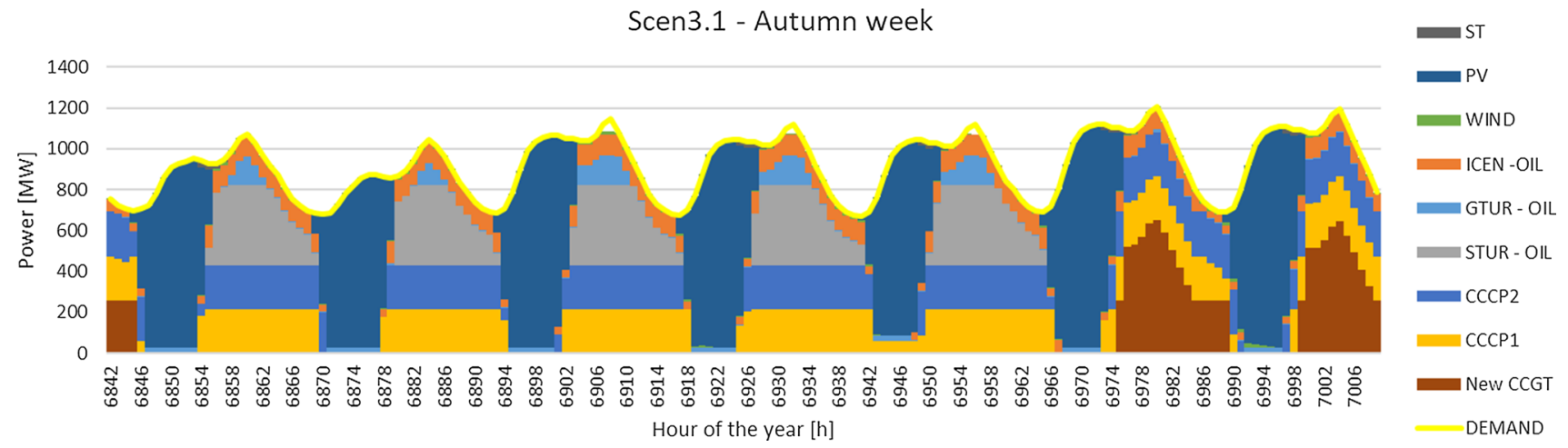

\section{Appendix 3}

Dispa-SET additional simulation results graphs.

\section{Simulation scenarios}

Scen2.1s2.
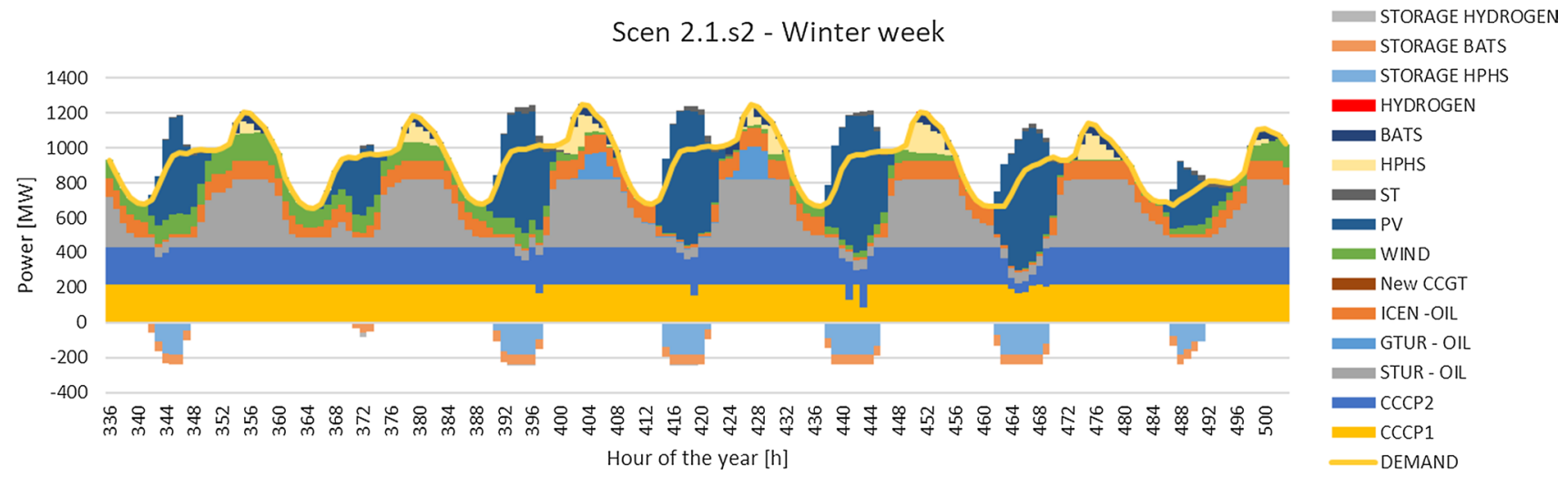

Scen 2.1.s2 - Spring week

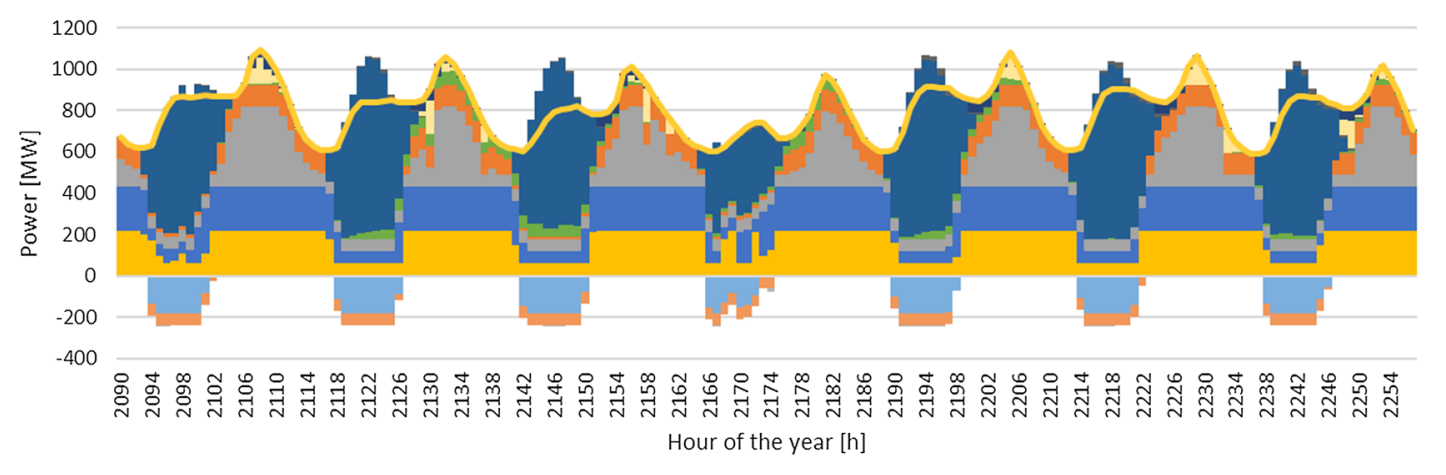

STORAGE HYDROGEN
STORAGE BATS
STORAGE HPHS
HYDROGEN
BATS
HPHS
ST
PV
WIND
NeW CCGT
ICEN -OIL
GTUR - OIL
STUR - OIL
CCCP2
CCCP1
DEMAND


Scen 2.1.s2 - Summer week

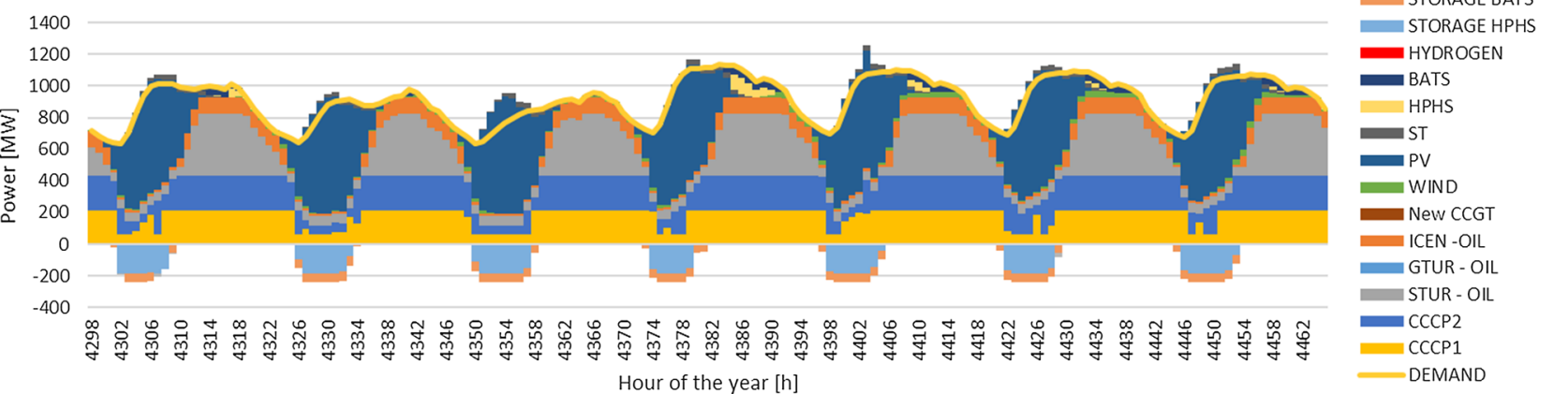

Scen 2.1.s2 - Autumn week

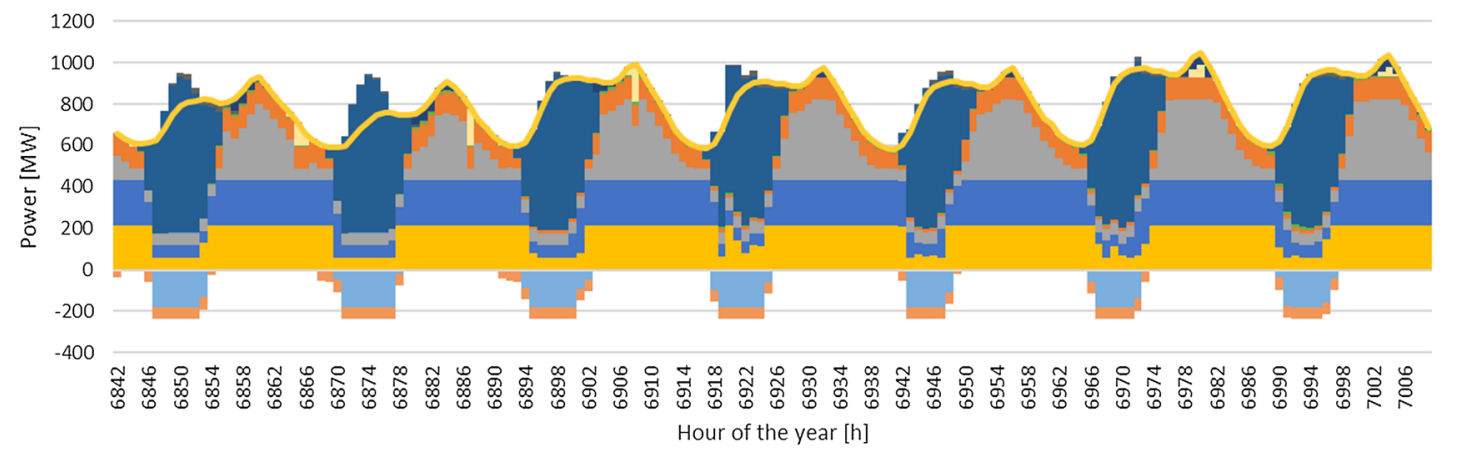

STORAGE HYDROGEN STORAGE BATS STORAGE HPHS HYDROGEN BATS HPHS ST PV WIND New CCGT ICEN -OIL GTUR - OIL STUR - OIL CCCP2 CCCP1 DEMAND

\section{References}

1. Directive 2009/28/EC of the European Parliament and of the Council of 23 April 2009 on the promotion of the use of energy from renewable sources and amending and subsequently repealing Directives 2001/77/EC and 2003/30/EC.

2. Directive (EU) $2018 / 2001$ of the European Parliament and of the Council of 11 December 2018 on the promotion of the use of energy from renewable sources.

3. EU SHARES tool. 2021. https://ec.europa.eu/eurostat/web/energy/data/shares. Accessed 09 Sept 2021.

4. Cyprus' Integrated National Energy and Climate Plan under the Regulation (EU) 2018/1999 of the European Parliament and of the Council of 11 December 2018 on the Governance of the Energy Union and Climate Action. 2021. https://ec.europa.eu/energy/sites/ener/files/ documents/cy_final_necp_main_en.pdf. Accessed 9 Sept 2021

5. International Renewable Energy Agency (IRENA): Renewable Energy Roadmap for the Republic of Cyprus. 2021. https://www.irena.org/ publications/2015/Jan/Renewable-Energy-Roadmap-for-the-Republic-of-Cyprus. Accessed 9 Sept 2021.

6. Taliotis C, Howells, Partasides G, Gardumi F. Cost-optimal scenario analysis for the Cypriot energy system. 2021. https://energy.gov.cy/ assets/entipo-iliko/\%CE\%9A\%CE\%A4\%CE\%97-cost\%20optimaization\%20Scenarios\%202017.pdf. Accessed 9 Sept 2021.

7. Afxentis S, Venizelou V, Makrides G, Georghiou GE, Efthymiou V. Review on policy framework for introducing energy storage technologies. 2021. https://energy.gov.cy/assets/entipo-iliko/JRC\%203-\%20STORAGE.pdf. Accessed 9 Sept 2021.

8. Roy A, Bandyopadhyay S. Introduction to isolated energy systems. In: Roy A, Bandyopadhyay S, editors. Wind power based isolated energy systems. Cham: Springer; 2019. https://doi.org/10.1007/978-3-030-00542-9_1.

9. Branco H, Castro R, Lopes A. Setas, Battery energy storage systems as a way to integrate renewable energy in small isolated power systems. Energy Sustain Dev. 2018;43:90-9. https://doi.org/10.1016/j.esd.2018.01.003.

10. Ribeiro LA, Saavedra OR, Lima SL, de Matos JG, Bonan G. Making isolated renewable energy systems more reliable. Renew Energy. 2012;45:221-31. https://doi.org/10.1016/j.renene.2012.02.014.

11. Hadjipaschalis I, Poullikkas A, Efthimiou V. Overview of current and future energy storage technologies for electric power applications. Renew Sustain Energy Rev. 2009;13(6-7):1513-22. https://doi.org/10.1016/j.rser.2008.09.028.

12. Kolokotsa D, Kampelis N, Mavrigiannaki A, et al. On the integration of the energy storage in smart grids: technologies and applications. Energy Storage. 2019;1: e50. https://doi.org/10.1002/est2.50.

13. Denholm $P$, Hand $M$. Grid flexibility and storage required to achieve very high penetration of variable renewable electricity. Energy Policy. 2011;39(3):1817-30. https://doi.org/10.1016/j.enpol.2011.01.019. 
14. Bullich-Massagué E, Cifuentes-García F, Glenny-Crende I, Cheah-Mañé M, Aragüés-Peñalba M, Díaz-González F, Gomis-Bellmunt O. A review of energy storage technologies for large scale photovoltaic power plants. Appl Energy. 2020;274: 115213. https://doi.org/10. 1016/j.apenergy.2020.115213.

15. Alves $M$, Segurado R, Costa M. On the road to $100 \%$ renewable energy systems in isolated islands. Energy. 2020;198: 117321. https://doi. org/10.1016/j.energy.2020.117321.

16. Psarros GN, Dratsas PA, Papathanassiou SA. A comparison between central- and self-dispatch storage management principles in island systems. Appl Energy. 2021;298: 117181. https://doi.org/10.1016/j.apenergy.2021.117181.

17. Brinkerink M, Gallachóir OB, Deane P. Building and calibrating a country-level detailed global electricity model based on public data. Energy Strategy Rev. 2021;33: 100592. https://doi.org/10.1016/j.esr.2020.100592.

18. Pavičević M, Mangipinto A, Nijs W, Lombardi F, Kavvadias K, Jiménez Navarro JP, Colombo E, Quoilin S. The potential of sector coupling in future European energy systems: soft linking between the Dispa-SET and JRC-EU-TIMES models. Appl Energy. 2020;267: 115100. https:// doi.org/10.1016/j.apenergy.2020.115100.

19. Gourbi A, et al. Numerical study of a hybrid photovoltaic power supply system. J Power Technol. 2016;96(2):137-44.

20. Graça Gomes J, Xu HJ, Yang Q, Zhao CY. An optimization study on a typical renewable microgrid energy system with energy storage. Energy. 2021;234: 121210. https://doi.org/10.1016/j.energy.2021.121210.

21. Kavvadias K, Hidalgo Gonzalez I, Zucker A, Quoilin S. Integrated modelling of future EU power and heat systems: The Dispa-SET v2.2 open-source model, JRC Technical Report, EU Commission. 2018.

22. Transmission System Operator of Cyprus (TSOC). https://tsoc.org.cy/. Accessed 10 Sept 2021.

23. Entso-e:Transparency platform. 2021. https://transparency.entsoe.eu/dashboard/show. Accessed 10 Sept 2021.

24. JRC-EU-TIMES model. 2021. https://ec.europa.eu/jrc/en/scientific-tool/jrc-eu-times-model-assessing-long-term-role-energy-technologi es. Accessed 10 Sept 2021.

25. Electricity Authority of Cyprus. 2021. https://www.eac.com.cy/EN/RegulatedActivities/Generation/powerstationcapacity/Pages/default. aspx. Accessed 10 Sept 2021.

26. Cyprus Energy Regulatory authority: 2019 National Report to the European Commission for the year 2018. https://www.ceer.eu/natio nal-reporting-2019. Accessed 8 Oct 2021.

27. CERA Annual Report 2019-Greek version, ISSN 2421-8472. https://www.cera.org.cy/Templates/00001/data/ektheseis/2019_gr.pdf. Accessed 5 Jan 2022.

28. EuroAsia Interconnector. 2021. https://euroasia-interconnector.com/. Accessed 8 Oct 2021.

29. Evaluating the potential and defining a policy framework for Demand Response (DR), Distributed Generation (DG), Renewable Energy Sources (RES) and Energy Storage (ES) in Cyprus, JRC, 2019. https://energy.gov.cy/assets/entipo-iliko/JRC\%20-\%20SYNOPSIS\%20OF\% 20RESULTS.pdf. Accessed 5 Jan 2022.

30. Integration of a high share of variable RES in the Cyprus power system Project summary - version 1.6, JRC, 2017. https://energy.gov.cy/ assets/entipo-iliko/CYPRUS\%20RESGRID\%20SUMMARY\%20V16.pdf. Accessed 5 Jan 2022.

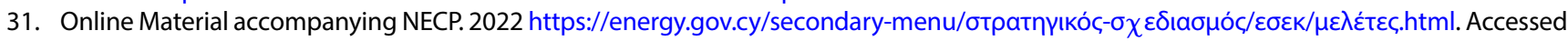
5 Jan 2022.

Publisher's Note Springer Nature remains neutral with regard to jurisdictional claims in published maps and institutional affiliations. 